\title{
Corona formation around monazite and xenotime during greenschist-facies metamorphism and deformation
}

\author{
Felix Hentschel ${ }^{1}$, Emilie Janots ${ }^{2}$, Claudia A. Trepmann ${ }^{1}$, Valerie Magnin ${ }^{2}$, and Pierre Lanari ${ }^{3}$ \\ ${ }^{1}$ Department for Earth and Environmental Sciences, Ludwig-Maximilians-Universität München, \\ Munich, Germany \\ ${ }^{2}$ Univ. Grenoble 1, ISTerre, Grenoble, France \\ ${ }^{3}$ Univ. Bern, Institute of Geological Sciences, Bern, Switzerland
}

Correspondence: Felix Hentschel (felix.hentschel@lmu.de)

Received: 24 October 2019 - Revised: 31 July 2020 - Accepted: 20 September 2020 - Published: 15 October 2020

\begin{abstract}
Epidote/allanite-fluorapatite coronae around monazite and xenotime are investigated in Permian pegmatites deformed under greenschist-facies conditions during Alpine tectonometamorphism in the Austroalpine basement, Eastern Alps. The aim was to evaluate the replacement reactions involved in the formation of a corona microstructure, its age and relation to deformation. In the corona core, monazite and xenotime single crystals show domains with different composition and age. Monazite (Mnz1) and xenotime (Xen1) dating by electron microprobe (EPM) reveals an age of 250-287 Ma, consistent with the Permian magmatic age of the pegmatites. These are partly replaced by secondary monazite (Mnz2) and xenotime (Xen2) compositions yielding younger Mesozoic (170-210 Ma) and Alpine (30-120 Ma) ages. The same crystallographic orientation of the primary and secondary monazite and xenotime indicates interface-coupled dissolution-precipitation reactions. Allanite $\mathrm{U}-\mathrm{Th}-\mathrm{Pb}$ dating by laser ablation inductively coupled mass spectrometry in the corona revealed an age of $60 \pm 6 \mathrm{Ma}$, interpreted as the age of corona formation. The coronae around monazite consist of an inner zone of equant fluorapatite grains surrounded by prismatic allanite, which are surrounded by epidote enriched in heavy rare earth elements (HREEs) and REE-poor epidote grains. Compared to coronae around monazite, fluorapatite has higher REE contents and no allanite occurs in the coronae surrounding the xenotime. General reactions for monazite and xenotime breakdown can be written as follows:

$$
\begin{aligned}
& \text { Mnz1 + (Si, Ca, Al, Fe, F)fluid } \rightarrow \text { Mnz2 + LREE-Ap + Aln + HREE-Ep + Ep + (Th, U) } \mathrm{O}_{2}+(\mathrm{Th}, \mathrm{U}) \mathrm{SiO}_{4}, \\
& \text { Xen1 + (Si, Ca, Al, Fe, F)fluid } \rightarrow \text { Xen2 + HREE-Ap + HREE-Ep }+ \text { Ep }+\left(\text { Th, U) } \mathrm{O}_{2} .\right.
\end{aligned}
$$

The amount of replacement (judged by the relative proportions of monazite and fluorapatite) is low for monazite included in tourmaline but high within the mylonitic foliation. This dependence on the degree of replacement on the local surrounding microfabric indicates that fluid availability along grain boundaries in the matrix and cracks controlled reaction advancement, allowing the elementary mass transfer required for corona formation (e.g. input of $\mathrm{Ca}, \mathrm{Al}, \mathrm{Si}, \mathrm{Fe}, \mathrm{F}$ ). The oblate shape of the coronae aligned within the foliation of the pegmatites and the deflected foliation around the coronae, without an outer rim of prismatic epidote showing signs of deformation, indicate that the main stage of corona formation took place during deformation and reactions were still ongoing after the main stage of deformation. The corona microstructure documents replacement reactions of a single reactant into multiple distinct mineral growth zones by dissolution and precipitation processes at nonisostatic, greenschist-facies conditions, which prevailed in the area to the north of the Defereggen-Antholz-Vals shear zone between the middle Cretaceous and the Oligocene. These reactions ceased before being completed, and REE gradients within single grains within the corona and on the thin-section scale are preserved, which suggests restricted and/or episodic transport of REE in the fluid phase and/or availability of fluid.
\end{abstract}




\section{Introduction}

Understanding the behaviour of monazite and xenotime in metamorphic reactions during deformation is of great importance in metamorphic petrology. Monazite $\left(\mathrm{LREEPO}_{4}\right.$, where LREE means light rare earth element) and xenotime (HREEPO 4 , where HREE means heavy rare earth element) are widespread accessory minerals and, together with allanite $\left.\left(\mathrm{CaREEAl}_{2} \mathrm{Fe}_{2} \mathrm{Si}_{2} \mathrm{O}_{7}\right]\left[\mathrm{SiO}_{4}\right](\mathrm{O}, \mathrm{F})(\mathrm{OH}, \mathrm{O})\right)$, the most important REE minerals in metapelitic (e.g. Spear and Pyle, 2002) and (meta-)granitic rocks (e.g. Bea, 1996; Förster, 1998a, b). As such they have attracted much research attention during the last decades (see Engi, 2017, for a review). Monazite and xenotime are both orthophosphate minerals, which consist of alternating $\mathrm{PO}_{4}$ tetrahedra and $\mathrm{REEO}_{9}$ polyhedra. Thorium and uranium can be inserted into the crystal structure via the coupled substitutions: Th or $\mathrm{U}+\mathrm{Si}=\mathrm{REE}+\mathrm{P}$ (huttonite substitution in monazite; thorite in xenotime) and Th or $\mathrm{U}+$ $\mathrm{Ca}=2$ REE (cheralite substitution).

Two main characteristics of monazite and xenotime are important for their use in metamorphic petrology. First, trace element diffusion is generally slow in major minerals, especially at greenschist-facies conditions (Spear and Pyle, 2002; Raimondo et al., 2017). Therefore, trace elements in rockforming and accessory minerals, such as REE and Y, contain valuable information about the growth history of the minerals and the microfabric development of the rock in general. One important application is for example the YAG thermometer using Y contents in garnet and monazite or xenotime (Pyle and Spear, 2000; Pyle et al., 2001). Additionally, the REE distributions between monazite and xenotime can be used as a thermometer (e.g. Gratz and Heinrich, 1997; 1998; Andrehs and Heinrich, 1998). Second, because monazite and xenotime readily incorporate $\mathrm{Th}$ and $\mathrm{U}$ during growth, both can furthermore be used for radiometric dating. Since the $\mathrm{Pb}$ in both is mostly radiogenic, chemical dating methods, for example by electron microprobe (EMP), can be used (Montel et al., 1996; Williams et al., 2007; Suzuki and Kato, 2008). If these reactions can further be related to deformation during metasomatism and pressure-temperature $(P-T)$ conditions, $\mathrm{U} / \mathrm{Pb}-\mathrm{Th}$ dating of these minerals can give valuable information on the tectonometamorphic history of the rock.

The stability of monazite during metamorphism in both metasediments and metagranitoids is characterized by their breakdown/disappearance at mid-temperature conditions and their (re-)appearance at higher temperatures. In metasediments, monazite is replaced by allanite at about $450^{\circ} \mathrm{C}$ during prograde metamorphism, which in turn is replaced by monazite at $550-600^{\circ} \mathrm{C}$ (e.g. Wing et al., 2003; Janots et al., 2008; Goswami-Banerjee and Robyr, 2015). In rocks with low $\mathrm{Ca}$ and $\mathrm{Al}$ bulk compositions, monazite is stabilized and allanite might not occur at all. Analogously, xenotime is replaced by and replaces heavy rare earth element (HREE)-rich epidote/clinozoisite during metamorphism. The stability of xenotime might also be controlled by the formation or destruction of garnet, as garnet might control the $\mathrm{Y}$ budget of the rocks (Spear and Pyle, 2002).

Apart from the involvement in these characteristic reactions, monazite and xenotime have been found to be susceptible to fluid-mediated breakdown and alteration processes. One peculiar product of monazite and xenotime breakdown reactions is the formation of fluorapatite-allanite-epidote coronae around monazite or xenotime relics, recording incomplete replacement reactions (e.g. Finger et al., 1998; Broska et al., 2005; Majka and Budzyń, 2006; Budzyń et al., 2011, 2017; Ondrejka et al., 2012, 2016; Budzyń and Jastrzębski, 2016; Lo Pò et al., 2016). These have been interpreted to be the product of the dissolution of monazite/xenotime and the subsequent precipitation of fluorapatite and REE-bearing epidote-group minerals. While the formation of such microstructures with distinctive zones of the corona minerals has been discussed in the literature, Finger et al. (1998) attributes the concentric alteration structures to diffusion, while other authors attribute them to solubility differences of the freed elements in the fluid phase (Broska et al., 2005; Upadhyay and Pruseth, 2012). Subsequently, the exact mechanism of corona formation remains uncertain and more detailed investigation of the microstructural, textural and chemical variations need to be done.

In this study, the composition age and microfabric of fluorapatite-allanite-epidote coronae around monazite and xenotime in mylonitic pegmatites from the Austroalpine basement in the Eastern Alps are used to infer the involved reaction mechanisms, the scale of mass transfer, the mechanisms of corona formation and their relationship to deformation.

\section{Geological setting and samples}

The coronae around monazite and xenotime occur in deformed granitic pegmatites from the Austroalpine basement, Eastern Alps, Italy. The pegmatites occur within the polymetamorphic Austroalpine basement units of the KoralpeWölz nappe system, between the western Tauern Window in the north and the Defereggen-Antholz-Vals (DAV) shear zone in the south (Fig. 1; e.g. Hofmann et al., 1983; Stöckhert, 1985, 1987; Mancktelow et al., 2001; Schmid et al., 2004). Given their association with migmatites and the lack of parental granites, they are interpreted to have formed by anatexis from K-free paragneisses (Stöckhert, 1987). After separation from there crystalline residuum, the melt intruded into the various rocks now forming the Austroalpine basement (i.e. paragneisses, white micagarnet schists and gneisses, graphite schists, tourmaline- $\mathrm{Mg}$ chlorite schists, quartzites, calc-silicate gneisses, amphibolites, augen gneisses, and marbles, Hofmann et al., 1983). 
The crystallization of the pegmatites was dated by $\mathrm{Rb} / \mathrm{Sr}$ whole-rock analyses to the Permian $(262 \pm 7 \mathrm{Ma}$; Borsi et al., 1980), which is generally consistent with other pegmatite occurrences in the Austroalpine basement yielding ages from 245 to $280 \mathrm{Ma}$ (e.g. $\mathrm{Sm} / \mathrm{Nd}$ and $\mathrm{Rb} / \mathrm{Sr}$ data from magmatic garnet and whole rock: Habler et al., 2009; Knoll et al., 2018). The timing and conditions of Alpine deformation that affected this area have been debated in the literature over several decades. An early Alpine deformation before $100 \mathrm{Ma}$, metamorphic conditions of $450 \pm 50^{\circ} \mathrm{C}$ and about $0.7 \mathrm{GPa}$, has been proposed by Stöckhert (1984) on the base of microstructural and white mica $\mathrm{K}-\mathrm{Ar}$ data. This age corresponds to an Eoalpine (Cretaceous) tectonometamorphic event recorded from other units of the eastern Austroalpine basement (e.g. Thöni and Miller, 1996; Habler et al., 2009). South of the western Tauern Window, Rb-Sr muscovite cooling ages decrease from 250 to $30 \mathrm{Ma}$ from the DAV towards the north (Borsi et al., 1978), K-Ar muscovite cooling ages range typically between 100 and $60 \mathrm{Ma}$, and $\mathrm{Rb}-\mathrm{Sr}$ and $\mathrm{K}-\mathrm{Ar}$ biotite cooling ages range between 30 and $15 \mathrm{Ma}$ (e.g. Steenken et al., 2002). These geochronological and geothermobarometric data consistently indicate that the rocks in this area were at greenschist-facies conditions from the middle Cretaceous to the Oligocene (Stöckhert, 1984). The $\mathrm{Rb}-\mathrm{Sr}$ ages of newly formed white mica just to the north of the DAV yield ages between 33 and $30 \mathrm{Ma}$ (Müller et al., 2000). These ages were interpreted to correlate with the sinistral movement and associated deformation along the DAV (Kleinschrodt, 1987). In general, the mylonitic fabrics related to the DAV are assumed to have formed at about $300-400^{\circ} \mathrm{C}$, with temperature conditions gradually increasing towards the north as indicated by the microfabric and isotopic ages (e.g. Kleinschrodt, 1987; Stöckhert, 1987; Schulz, 1994; Mancktelow et al., 2001; Müller et al., 2000). Additionally, the amount of uplift and erosion since coeval intrusion of the magmatic bodies increases from about $10 \mathrm{~km}$ in the eastern part of the Rieserferner pluton to about 15 to $25 \mathrm{~km}$ in the Rensen area in the west. This is well documented by geochronological data (e.g. Steenken et al., 2002) and is represented by the metamorphic overprint of subvolcanic dikes in the west and largely preserved magmatic fabrics in the east (Trepmann et al., 2004). Because of these different gradients from north to south as well as west to east, a clear distinction between the microfabric overprint at the Eoalpine higher grade and DAV lower grade events appears problematic. This is also because of the stress and strain-rate variations during deformation in shear zones. Hence, a distinction between deformation occurring at higher- or under lower-greenschistfacies conditions is difficult (Hentschel et al., 2019).

The pegmatites are characterized by a Ca-poor composition that originated from water-rich anatectic melts (Stöckhert, 1987; Schuster and Stüwe, 2008). The magmatic assemblage of the pegmatites presented here is, with varying proportions, quartz, albitic plagioclase, $\mathrm{K}$-feldspar and muscovite (Table 1). Common accessory minerals are tour- maline, garnet, zircon, pyrite, fluorapatite, monazite and xenotime. Primary magmatic almandine garnet is Mn-rich and low in $\mathrm{Ca}$ (on average $\mathrm{Alm}_{68} \mathrm{Gro}_{4} \mathrm{Sp}_{26} \operatorname{Prp}_{2}$ ). Metamorphic garnet shows a higher $\mathrm{Ca}$ and lower $\mathrm{Fe}$ component $\left(\mathrm{Alm}_{34} \mathrm{GrO}_{45} \mathrm{Sp}_{20} \operatorname{Prp}_{1}\right)$. Metamorphic epidote and Febearing white mica $(2 \mathrm{wt} \% \mathrm{FeO})$ occur in the foliation plane of all deformed pegmatites (Fig. 2a). For a detailed description of the geochemistry and microfabric of the pegmatites, the reader is also referred to Stöckhert (1987) and Hentschel et al. (2019).

\section{Methods}

Thin sections were prepared from slices perpendicular to the foliation and parallel to the stretching lineation of the sample. These were taken to indicate the short $(Z)$ and long $(X)$ axes of the finite strain ellipsoid (Hentschel et al., 2019). All images presented are from these $X Z$ cuts. To judge the 3D shape of the coronae also a $Y Z$ cut was prepared. The fabric and composition of the coronae were investigated by polarized light and electron microscopy using standard petrographic thin sections. Thin sections were coated with a $\sim 5 \mathrm{~nm}$ thick carbon layer and imaged by backscattered electrons (BSEs) using a scanning electron microscope (Hitachi SU5000 at LMU Munich) equipped with an HKL NordlysNano high-sensitivity electron backscatter diffraction (EBSD) detector (Oxford Instruments). Crystallographic orientations were analysed by acquiring EBSD signals using AZtec analysis software (Oxford Instruments). We used a sample holder pre-tilted at $70^{\circ}$ with respect to the electron beam, an accelerating voltage of $20 \mathrm{kV}$ and a working distance of $20-25 \mathrm{~mm}$. Pole figures were plotted using the software Stereo32 and orientation relationships investigated using the MATLAB-based toolbox MTEX (https: //mtex-toolbox.github.io/, last access: 12 October 2020; e.g. Bachmann et al., 2010).

The chemical compositions of the fluorapatite and allanite were analysed by electron microprobe (EMP) measurements on a JEOL JXA-8230 at the ISTerre in Grenoble, with operating conditions of $15 \mathrm{kV}, 20 \mathrm{nA}$, and a beam diameter of about $1 \mu \mathrm{m}$ for allanite and $10 \mathrm{nA}$ and $10 \mu \mathrm{m}$ for fluorapatite. For fluorapatite $\mathrm{F}, \mathrm{Cl}$ and $\mathrm{Na}$ were measured first. For EMP dating of monazite and xenotime, the current was increased to 200 and $300 \mathrm{nA}$ respectively, and a thicker carbon coating of 55-60 nm was used. To measure the small quantities of $\mathrm{Pb}$ accurately, a counting time of $480 \mathrm{~s}$ was used. Counting times for $U$ and $T h$ of 160 and $300 \mathrm{~s}$ were used for monazite and of 300 and $160 \mathrm{~s}$ for xenotime, respectively (Table A1). To monitor instrumental drift, Madagascar monazite (e.g. Grand'Homme et al., 2018) was run as unknown (three points) before and after each analyses of samples. 
Table 1. Overview of the presented samples.

\begin{tabular}{|c|c|c|c|c|}
\hline Sample & Locality & Coordinates & Modal analysis & Accessory phases \\
\hline $\mathrm{FH} 21$ & Sambock & $46^{\circ} 51^{\prime} 31.9^{\prime \prime} \mathrm{N} 11^{\circ} 53^{\prime} 48.2^{\prime \prime} \mathrm{E}$ & Qz: $15 \%$, Plag: $65 \%$, Kfs: $15 \%$, Ms: $5 \%$ & Ap, Ep, Mnz, Xen, Grt, Zrc \\
\hline FH27 & Weitental & $46^{\circ} 51^{\prime} 13.0^{\prime \prime} \mathrm{N} 11^{\circ} 42^{\prime} 52.1^{\prime \prime} \mathrm{E}$ & Qz: $20 \%$, Plag: $65 \%$, Kfs: $5 \%$, Ms: $10 \%$ & Ap, Ep, Mnz, Grt, Zrc, Py \\
\hline FH36 & Weitental & $46^{\circ} 51^{\prime} 12^{\prime \prime} \mathrm{N} 11^{\circ} 42^{\prime} 48.6^{\prime \prime} \mathrm{E}$ & Qz: $85 \%$, Plag: $5 \%$, Kfs: $5 \%$, Ms: $5 \%$ & Ap, Ep, Mnz, Grt, Tur, Py \\
\hline KD75 & Sambock & $46^{\circ} 51^{\prime} 37.9^{\prime \prime} \mathrm{N} 11^{\circ} 53^{\prime} 49.3^{\prime \prime} \mathrm{E}$ & Qz: $20 \%$, Ab: $65 \%$, Kfs: $15 \%$, Ms: $5 \%$ & Ap, Ep, Mnz \\
\hline CT599 & Vals & $46^{\circ} 52^{\prime} 33^{\prime \prime} \mathrm{N} 11^{\circ} 37^{\prime} 28^{\prime \prime} \mathrm{E}$ & Qz: $10 \%$, Ab: $60 \%$, Kfs: $20 \%$, Tur: $10 \%$, Ms: $<1 \%$ & Ap, Ep, Mnz \\
\hline
\end{tabular}
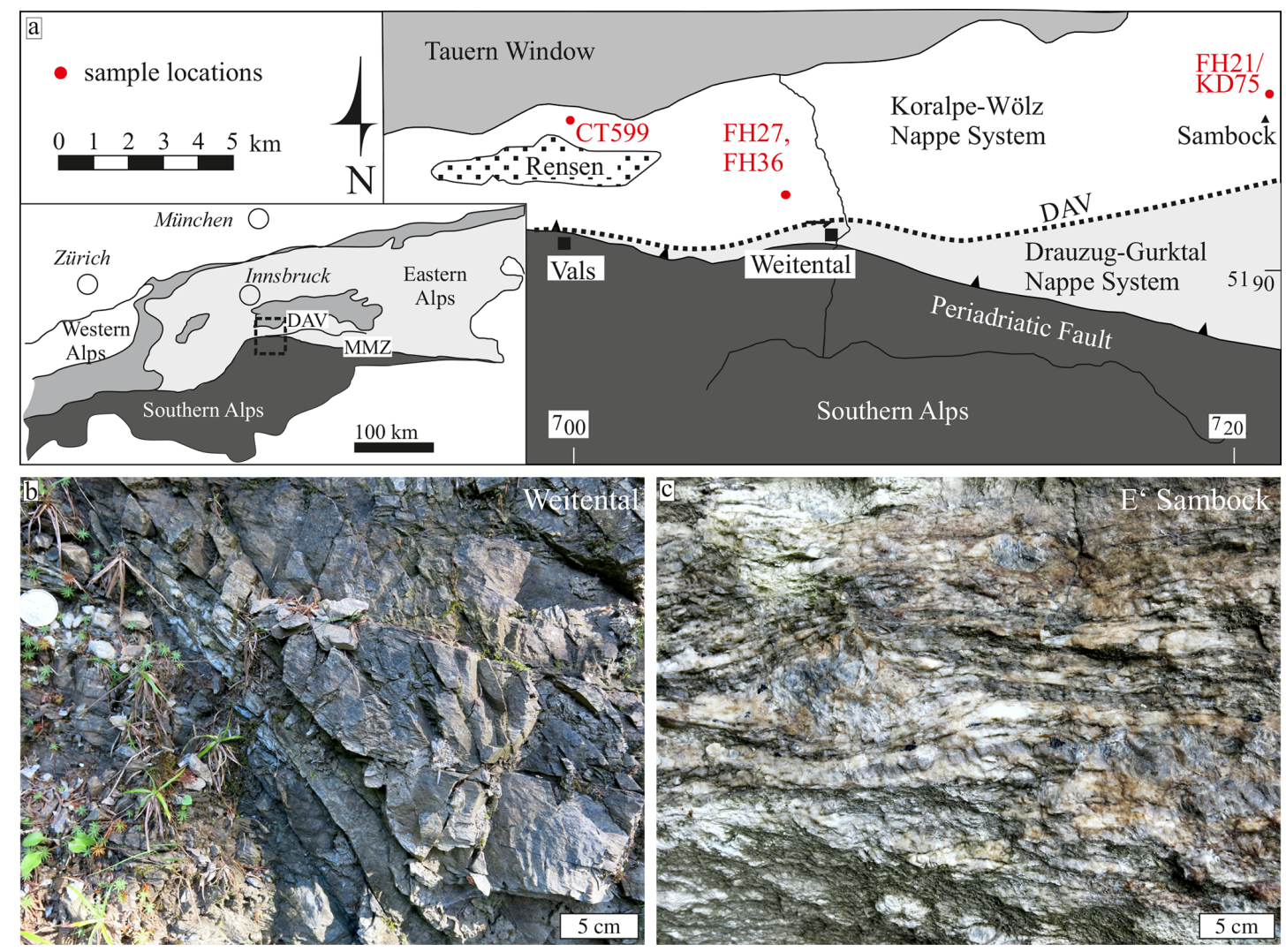

Figure 1. Simplified geological map of the study area. Investigated samples are highlighted in red (modified after Stöckhert, 1987). (b, c) Field photographs from the pegmatite occurring near Weitental (FH36) and at the crest east of Sambock (KD75).

Ages were calculated for every measurement point by solving the following formula (Montel et al., 1996):

$$
\begin{aligned}
\mathrm{Pb}= & \frac{\mathrm{Th}}{232}\left[\exp \left(\lambda^{232} \tau\right)-1\right] 208+\frac{\mathrm{U}}{238.04} 0.9928 \\
& \times\left[\exp \left(\lambda^{238} \tau\right)-1\right] 206+\frac{\mathrm{U}}{238.04} 0.0072 \\
& \times\left[\exp \left(\lambda^{235} \tau\right)-1\right] 207 .
\end{aligned}
$$

EMP measurement uncertainties $(3 \sigma)$ of monazite are in the range of 125,120 and $85 \mathrm{ppm}$ for $\mathrm{U}$, Th and $\mathrm{Pb}$, respectively, and for xenotime in the range of 135, 90 and $75 \mathrm{ppm}$ for $\mathrm{U}$, $\mathrm{Th}$ and $\mathrm{Pb}$, respectively. The errors for each age were propagated from these values using a Monte Carlo simulation contained in the software NiLeDAM (Seydoux-Guillaume et al.,
2012; Villa-Vialaneix et al., 2013). In the figures, only measurement points, for which an age was calculated, are displayed. The uncertainties of the weighted mean ages do only take account of the uncertainty of the single measurements and not the dispersion of the ages.

\section{$\mathrm{U}-\mathrm{Th}-\mathrm{Pb}$ allanite geochronology}

Allanite grains in the corona were dated in situ using an ELAN DRC-e quadrupole laser ablation inductively coupled mass spectrometer (LA-ICP-MS) with a $193 \mathrm{~nm} \mathrm{ArF}$ excimer laser at the Institute of Geological Sciences, University of Bern. The analytical procedure followed that of Burn et al. (2017). For ablation the laser was tuned to a repetition rate of $9 \mathrm{~Hz}$ and a surface energy density of $2.5 \mathrm{~J} \mathrm{~cm}^{-2}$. 
The signal acquisition followed a pre-ablation stage at $1 \mathrm{~Hz}$ and $2.5 \mathrm{~J} \mathrm{~cm}^{-2}$. Spot sizes of $24 \mu \mathrm{m}$ were used during measurement and $32 \mu \mathrm{m}$ for pre-ablation. The ablated material was transported from the ablation cell to the plasma as an aerosol using a gas mixture made of $\mathrm{He}\left(1 \mathrm{~L} \mathrm{~min}^{-1}\right)$ and $\mathrm{H}_{2}$ (0.08 $\left.\mathrm{L} \mathrm{min}^{-1}\right)$.

Allanite $\mathrm{Th} / \mathrm{Pb}$ and $\mathrm{U} / \mathrm{Pb}$ ratios were obtained by using the Plešovice zircon (Sláma et al., 2008) as a primary reference material and the non-matrix-matched standardization procedure of Burn et al. (2017) included in the inhouse software package TRINITY. The primary reference material Plešovice returned a weighted average ${ }^{232} \mathrm{Th} /{ }^{208} \mathrm{~Pb}$ age of $334.5 \pm 8.4 \mathrm{Ma}(2 \sigma, \mathrm{MSWD}=1.0 ; 14 / 16$ analyses $)$ and a weighted average ${ }^{238} \mathrm{U} /{ }^{206} \mathrm{~Pb}$ age of $336.9 \pm 2.6 \mathrm{Ma}$ $(2 \sigma, \mathrm{MSWD}=0.6 ; 14 / 16$ analyses $)$. The BONA $^{\mathrm{b}}$ allanite was used as a secondary standard to test the calibration. The weighted average common-lead corrected ages of BONA are $30.7 \pm 0.6 \mathrm{Ma}(2 \sigma, \mathrm{MSWD}=0.1 ; 6 / 6$ analyses) for the ${ }^{232} \mathrm{Th} /{ }^{208} \mathrm{~Pb}$ system, with a lower intercept U$\mathrm{Pb}$ age of $34.4 \pm 6.7 \mathrm{Ma}(2 \sigma, \mathrm{MSWD}=0.4 ; 6 / 6$ analyses $)$ for the ${ }^{238} \mathrm{U} /{ }^{206} \mathrm{~Pb}$ system, in agreement within uncertainty with previous results (Gregory et al., 2007; von Blanckenburg 1992; Burn et al., 2017). Every single-spot analysis consisted of $20 \mathrm{~s}$ of washout, $40 \mathrm{~s}$ of background counting, $\sim 10 \mathrm{~s}$ of pre-ablation and $60 \mathrm{~s}$ of measurement. Each analytical session with a maximum duration of $1 \mathrm{~h}$ included the analysis of (1) the primary reference material Plešovice, (2) the secondary reference material (CAP) every 10 analyses of the allanite grains and (3) the primary reference material Plešovice. Data are available in the Supplement.

\section{Results}

\subsection{Coronae around monazite}

Monazite single crystals are systematically surrounded by a rim of fluorapatite, followed by a rim of allanite, which grades into epidote in the outer rim (Figs. 2, 3). These corona microstructures indicate partial replacement of the monazite. The coronae are typically oblate shaped with long axes varying from $60 \mu \mathrm{m}$ up to over $600 \mu \mathrm{m}$ and an aspect ratio of up to 2 (Figs. 2, 3). The coronae are aligned within the mylonitic foliation, which is deflected around it (Fig. 2a, c). The size and shape of the preserved mostly elongate monazites is generally anhedral with long axes ranging from a few tens of micrometres up to several hundred micrometres ( $\mu \mathrm{m}$; Figs. 2 and 3). Elongate monazite is mostly but not necessarily aligned within the sample's foliation plane (compare e.g. Fig. 2b and f).

Locally fluorapatite-allanite coronae without a monazite core are observed, either representing a non-centred cut of the corona structure or indicating complete replacement of monazite (Fig. 3c-f). In these cases, only fluorapatite with or without small allanite and thorite grains occurs. The size of the fluorapatite zone around the monazite is especially thin when the corona is included in tourmaline, indicating that the monazite is largely preserved (Fig. 3a, b). By contrast, monazite grains in the mylonitic matrix (Fig. 2) or, for example, located near a quartz-filled crack within a tourmaline (Fig. 3c, d) are largely replaced. The dependence of the degree of replacement on the local mineral assemblage is also characterized by the largely missing fluorapatite zone between the monazite and pyrite in Fig. 2d. The fluorapatite and allanite/epidote zones are mostly broader parallel to the foliation and shorter perpendicular to it (Figs. 2, 3). Yet, the prismatic-to-columnar epidote crystals of the outer zone grew mostly with their long axes perpendicular to the fluorapatite zone, which can be at a high angle to the foliation (Fig. 3e, f). The microfabric of about 10 coronae in five pegmatite samples was analysed in detail (Fig. 1, Table 1). Among these, two coronae around monazite in sample FH21 (Fig. 2e) and FH27 (Fig. 2f) as well as one around xenotime in sample FH21 (Fig. 10b) were chosen for further chemical and geochronological investigations.

\subsubsection{The monazite core}

The monazite from sample $\mathrm{FH} 21$ has an irregular outline with embayments and isolated patches surrounded by fluorapatite (Figs. 2e, 4). The element distributions can be separated into compositionally different areas, which correlate to their EMP ages. The monazite core from sample FH27, with a long axis of about $200 \mu \mathrm{m}$, is one of the largest observed preserved monazite grains in our samples. It has an ellipsoidal shape (Figs. 2f, 5) and many inclusions, mostly of fluorapatite (high Ca content, Fig. 5b), thorite (high Th, Fig. 5d), pyrite, xenotime (high Y, Fig. 5g) and quartz (high Si, Fig. 5a). The compositional variance within the monazite is principally similar to that in $\mathrm{FH} 21$, with primary compositions higher in $\mathrm{Ca}, \mathrm{Y}$ and $\mathrm{U}$ and lower in $\mathrm{Si}, \mathrm{La}$ and $\mathrm{Ce}$ contents. However, it is dispersed and does not form coherent domains as in corona of FH21 (compare Figs. 4, 5).

From the measured $\mathrm{U}, \mathrm{Th}$ and $\mathrm{Pb}$ contents (Table 2), ages were calculated according to Eq. (1) and plotted in Fig. 6a. Based on the EMP ages, three different groups were identified by the software NiLeDAM (Seydoux-Guillaume et al., 2012). The oldest age group ranges from 250 to $285 \mathrm{Ma}$ and is referred to as "Permian" (mean age $263 \pm 14 \mathrm{Ma}$ ). About $10 \%$ (3 of 32 measurements) of the measured points from FH27 and $53 \%$ of the measured points from FH21 (9 of 17 measurements) show Permian ages. The second age group ranges from 170 to $210 \mathrm{Ma}$ and is referred to as "Mesozoic" (mean age $194 \pm 15 \mathrm{Ma}$ ). It contains $10 \%$ of the measurements from $\mathrm{FH} 27$ and $47 \%$ from $\mathrm{FH} 21$. FH27 also shows a markedly separated group of younger ages between 30 and $120 \mathrm{Ma}$ and, which is referred to as "Alpine" (mean age $76 \pm 21 \mathrm{Ma}$ ). Sample FH36 consistently revealed monazite with compositions yielding Permian ages $(257 \pm 7 \mathrm{Ma})$ and few with Alpine ages (60-120 Ma). 

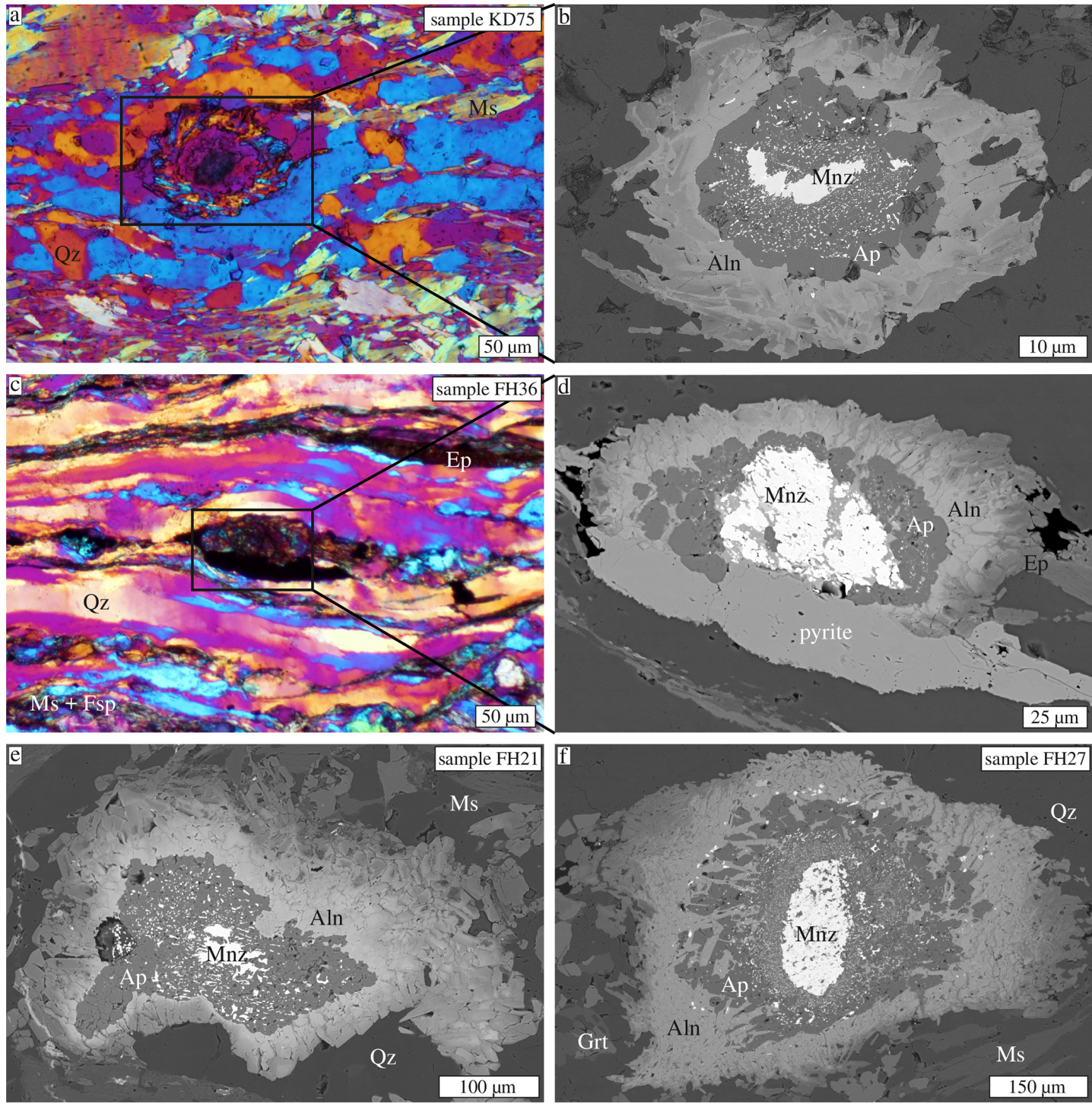

Figure 2. Micrographs of typical corona microstructures around monazite with fluorapatite, allanite and epidote zones. (a) Polarized light micrograph with compensator plate inserted showing corona within mylonitic pegmatite (sample KD75). Note the quartz layers bent around the corona. (b) BSE image of the corona microstructure shown in (a). (c) Polarized light micrograph with compensator plate inserted showing a corona around monazite in mylonitic pegmatite surrounded by pyrite (sample FH36). (d) BSE image of the corona microstructure shown in (c). (e, f) Corona microstructures chosen for detailed chemical and microstructural characterization and dating. All abbreviations for mineral names are from Whitney and Evans (2010).

Permian monazite from both coronae lies along the cheralite substitution line (Fig. 6b). The composition of secondary monazite, especially that of the Alpine age group, is shifted towards the huttonite substitution line (Fig. 6b), which reflects lower $\mathrm{Ca}$ and higher $\mathrm{Si}$ contents in altered areas during metamorphism (Fig. 4a). The difference in composition between the primary and secondary monazite again especially for that of the Alpine age group - is also reflected in the REE composition (Fig. 6c). By contrast, the Mesozoic age group does not show this clear compositional difference to the primary magmatic composition, which has the highest $\mathrm{Y} / \mathrm{LREE}$ ratios, the lowest REE content, and highest Th and U content (Fig. 6b, c). The Th/U ratios are generally low $(<30)$, especially for the magmatic domains where $\mathrm{UO}_{2}$ reaches a few percent (compare Fig. 3 from Grand'Homme et al., 2016a).

\subsubsection{The fluorapatite zone}

The fluorapatite zone directly surrounds the monazite core (Figs. 2b, d, e, f, 4h, 5h, 7). The phase boundary of the monazite to the fluorapatite zone is typically irregular and serrated (Fig. 7). The fluorapatite grain sizes generally increase 

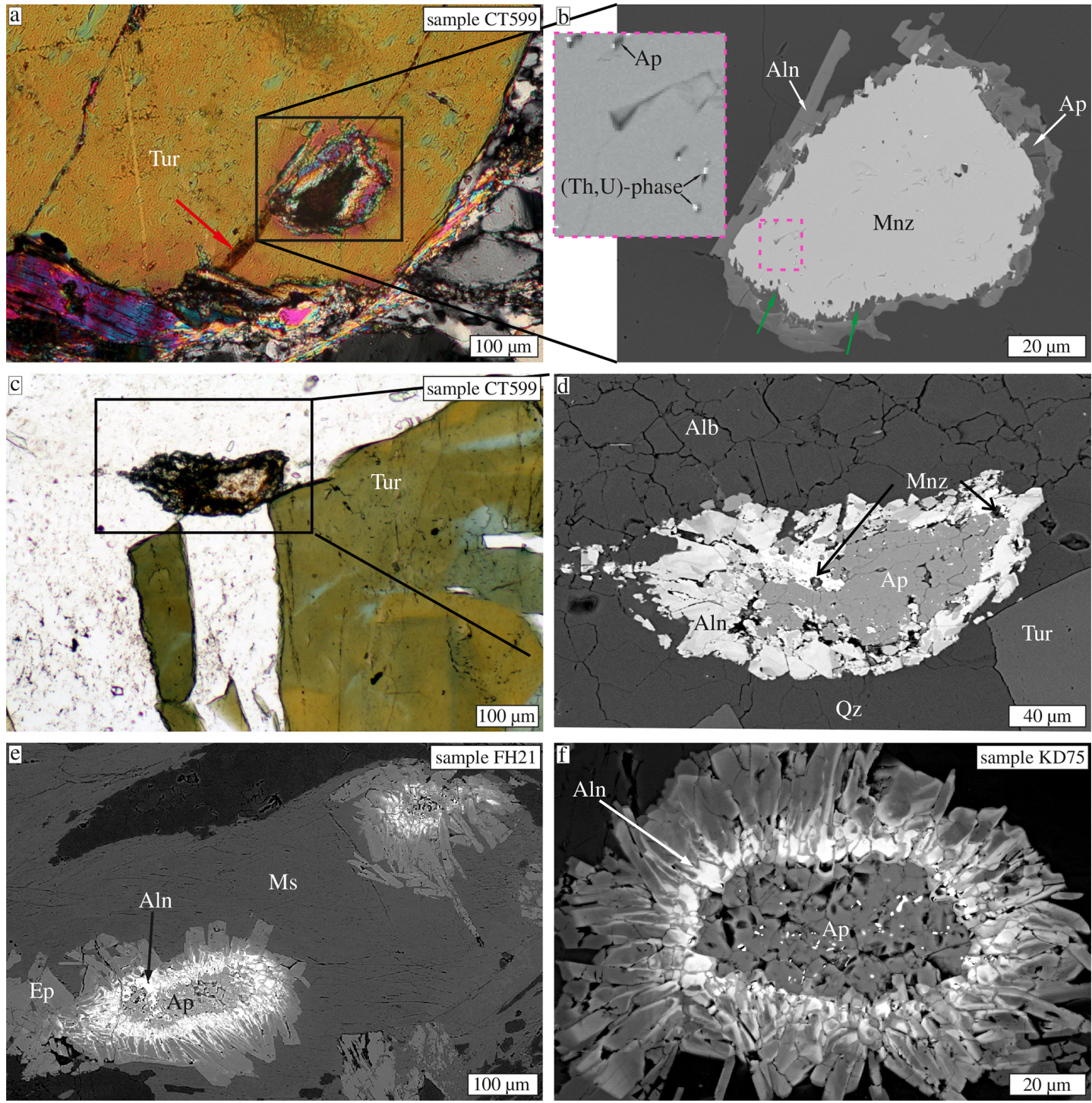

Figure 3. Coronae with varying relative proportions of fluorapatite to monazite. (a) Polarized light micrograph with crossed polarizers showing monazite inclusion in tourmaline located near an intragranular crack (red arrow, sample CT 599). (b) BSE image of monazite inclusion shown in (a) with thin fluorapatite and allanite rim. The inset shows that fluorapatite inclusions in the monazite are associated with (Th,U) phases. (c) Polarized light micrograph and (d) corresponding BSE image showing corona microstructure located at a quartz-filled fracture in tourmaline (sample CT 599). (e, f) Corona microstructures without monazite core. Note especially the prismatic shape of and chemical zoning within the allanite/epidote grains.

outwards, from as small as $<1 \mu \mathrm{m}$ adjacent to the monazite core up to $30 \mu \mathrm{m}$ at the outer rim. Close to the monazite, Ubearing thorite occurs as small $(<1-10 \mu \mathrm{m})$ grains dispersed between and as inclusions within the fluorapatite grains, similar to a symplectic structure (i.e, intergrowths of two new minerals formed at the expense of a previously stable one, e.g. Cahn, 1959; Abart et al., 2014; Fig. 7b, c). Allanite can be present as a thin film between two or at the edge between three fluorapatite grains. By contrast, close to the allanite zone, equant fluorapatite grains are poor in inclusions and with straight and even grain boundaries with $120^{\circ}$ angle at triple junctions, forming a foam structure. The boundary to the allanite zone is mostly relatively sharp and even (Figs. 2b, $\mathrm{d}, \mathrm{e}, 7 \mathrm{a}, \mathrm{c})$, but allanite grains can protrude into the fluorapatite zone as in the corona of sample FH27 (Fig. 2f).

The Y+REE content of fluorapatite from the monazite and xenotime coronae varies between 0.003 and $0.047 \mathrm{apfu}$ (atoms per formula unit). The spatial distribution of the REE contents in fluorapatite is random for the coronae from FH21 and FH27, and no difference is seen between the inner (finer grained) and outer (coarser grained) subzone in FH27 (Fig. 2f). The Y/LREE ratios are uniform and low. By con- 

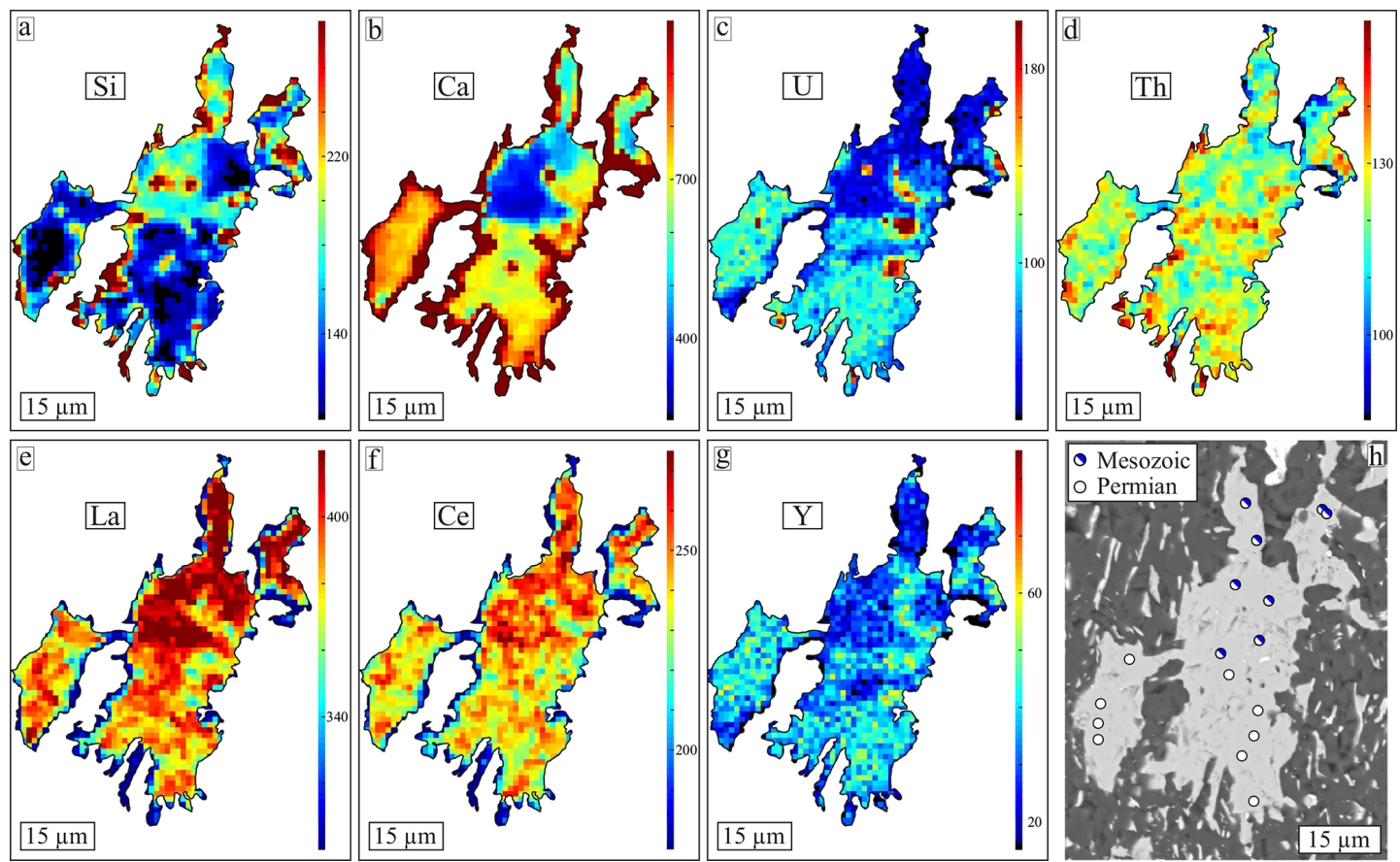

Figure 4. (a-g) Semi-quantitative element distribution maps for the monazite core from sample FH21 obtained by EMP (unit: counts; compare Fig. 2e). (h) BSE image showing measurement points for EMP dating and their corresponding age population.

Table 2. Representative monazite analyses (left: wt \%; right: apfu) obtained by EMP (b.d.l.: below detection limit).

\begin{tabular}{|c|c|c|c|c|c|c|c|c|c|c|c|}
\hline & FH21perm & FH21meso & FH27perm & FH27meso & FH27alp & & FH21perm & FH21meso & FH27perm & FH27meso & FH27alp \\
\hline $\mathrm{P}_{2} \mathrm{O}_{5}$ & 30.50 & 29.87 & 30.89 & 30.18 & 29.94 & $\mathrm{P}^{5+}$ & 1.005 & 0.982 & 1.005 & 0.996 & 0.987 \\
\hline $\mathrm{SiO}_{2}$ & 0.14 & 0.76 & 0.17 & 0.46 & 0.71 & $\mathrm{Si}^{4+}$ & 0.006 & 0.029 & 0.006 & 0.018 & 0.028 \\
\hline $\mathrm{ThO}_{2}$ & 4.55 & 4.56 & 4.82 & 3.89 & 4.49 & $\mathrm{Th}^{4+}$ & 0.040 & 0.040 & 0.042 & 0.034 & 0.040 \\
\hline $\mathrm{UO}_{2}$ & 1.55 & 0.19 & 3.77 & 1.30 & 0.36 & $\mathrm{U}^{4+}$ & 0.013 & 0.002 & 0.032 & 0.011 & 0.003 \\
\hline $\mathrm{PbO}$ & 0.11 & 0.04 & 0.20 & 0.07 & 0.02 & $\mathrm{~Pb}^{4+}$ & 0.001 & 0.000 & 0.002 & 0.001 & 0.000 \\
\hline $\mathrm{Y}_{2} \mathrm{O}_{3}$ & 2.01 & 1.16 & 2.81 & 2.63 & 0.99 & $\mathrm{Y}^{3+}$ & 0.037 & 0.021 & 0.051 & 0.048 & 0.018 \\
\hline $\mathrm{La}_{2} \mathrm{O}_{3}$ & 11.45 & 12.63 & 12.91 & 13.46 & 14.76 & $\mathrm{La}^{3+}$ & 0.164 & 0.181 & 0.183 & 0.193 & 0.212 \\
\hline $\mathrm{Ce}_{2} \mathrm{O}_{3}$ & 27.11 & 29.54 & 26.85 & 28.90 & 30.67 & $\mathrm{Ce}^{3+}$ & 0.386 & 0.420 & 0.378 & 0.412 & 0.437 \\
\hline $\mathrm{Pr}_{2} \mathrm{O}_{3}$ & 2.79 & 3.10 & 2.45 & 2.68 & 2.84 & $\operatorname{Pr}^{3+}$ & 0.040 & 0.044 & 0.034 & 0.038 & 0.040 \\
\hline $\mathrm{Nd}_{2} \mathrm{O}_{3}$ & 10.70 & 11.52 & 8.78 & 9.71 & 10.08 & $\mathrm{Nd}^{3+}$ & 0.149 & 0.160 & 0.120 & 0.135 & 0.140 \\
\hline $\mathrm{Sm}_{2} \mathrm{O}_{3}$ & 3.81 & 3.94 & 2.38 & 2.88 & 2.80 & $\mathrm{Sm}^{3+}$ & 0.051 & 0.053 & 0.031 & 0.039 & 0.038 \\
\hline $\mathrm{Gd}_{2} \mathrm{O}_{3}$ & 2.72 & 2.78 & 1.64 & 1.89 & 1.65 & $\mathrm{Gd}^{3+}$ & 0.035 & 0.036 & 0.021 & 0.024 & 0.021 \\
\hline $\mathrm{Dy}_{2} \mathrm{O}_{3}$ & b.d.l. & b.d.l. & b.d.l. & b.d.l. & b.d.l. & $\mathrm{Dy}^{3+}$ & - & - & - & - & - \\
\hline $\mathrm{Ho}_{2} \mathrm{O}_{3}$ & b.d.l. & b.d.l. & b.d.l. & b.d.l. & b.d.l. & $\mathrm{Ho}^{3+}$ & - & - & - & - & - \\
\hline $\mathrm{Er}_{2} \mathrm{O}_{3}$ & b.d.1. & b.d.l. & b.d.1. & b.d.l. & b.d.l. & $\mathrm{Er}^{3+}$ & - & - & - & - & - \\
\hline $\mathrm{Yb}_{2} \mathrm{O}_{3}$ & b.d.l. & b.d.l. & b.d.1. & b.d.l. & b.d.l. & $\mathrm{Yb}^{3+}$ & - & - & - & - & - \\
\hline $\mathrm{Lu}_{2} \mathrm{O}_{3}$ & b.d.l. & b.d.l. & b.d.l. & b.d.l. & b.d.l. & $\mathrm{Lu}^{3+}$ & - & - & - & - & - \\
\hline $\mathrm{CaO}$ & 1.57 & 0.54 & 2.12 & 0.88 & 0.58 & $\mathrm{Ca}^{2+}$ & 0.065 & 0.022 & 0.087 & 0.037 & 0.024 \\
\hline Total & 99.26 & 100.86 & 100.01 & 99.18 & 100.11 & $\Sigma$ & 1.999 & 1.996 & 1.999 & 1.994 & 1.993 \\
\hline
\end{tabular}

trast, grains from the rock's matrix generally have REE contents below the detection limit and varying Y contents.

\subsection{The allanite/epidote zone}

The allanite/epidote zone surrounds the fluorapatite zone. The complex structure of this zone varies between different coronae. Allanite grains in the innermost zone at the contact to fluorapatite are often equant. The outermost epidote grains often are elongate and form a concentric radiating palisadelike structure (Figs. 2, 3). In the allanite/epidote zone, the HREE/LREE ratio increases and the REE content decreases from the fluorapatite zone towards the outside of the corona (Fig. 8b). In the outermost part, the composition corresponds to Y-bearing epidote (Fig. 8b).

In the corona from FH21 a small compositional gap exists between allanites (XAln $=0.8-0.9$; where XAln $=$ 

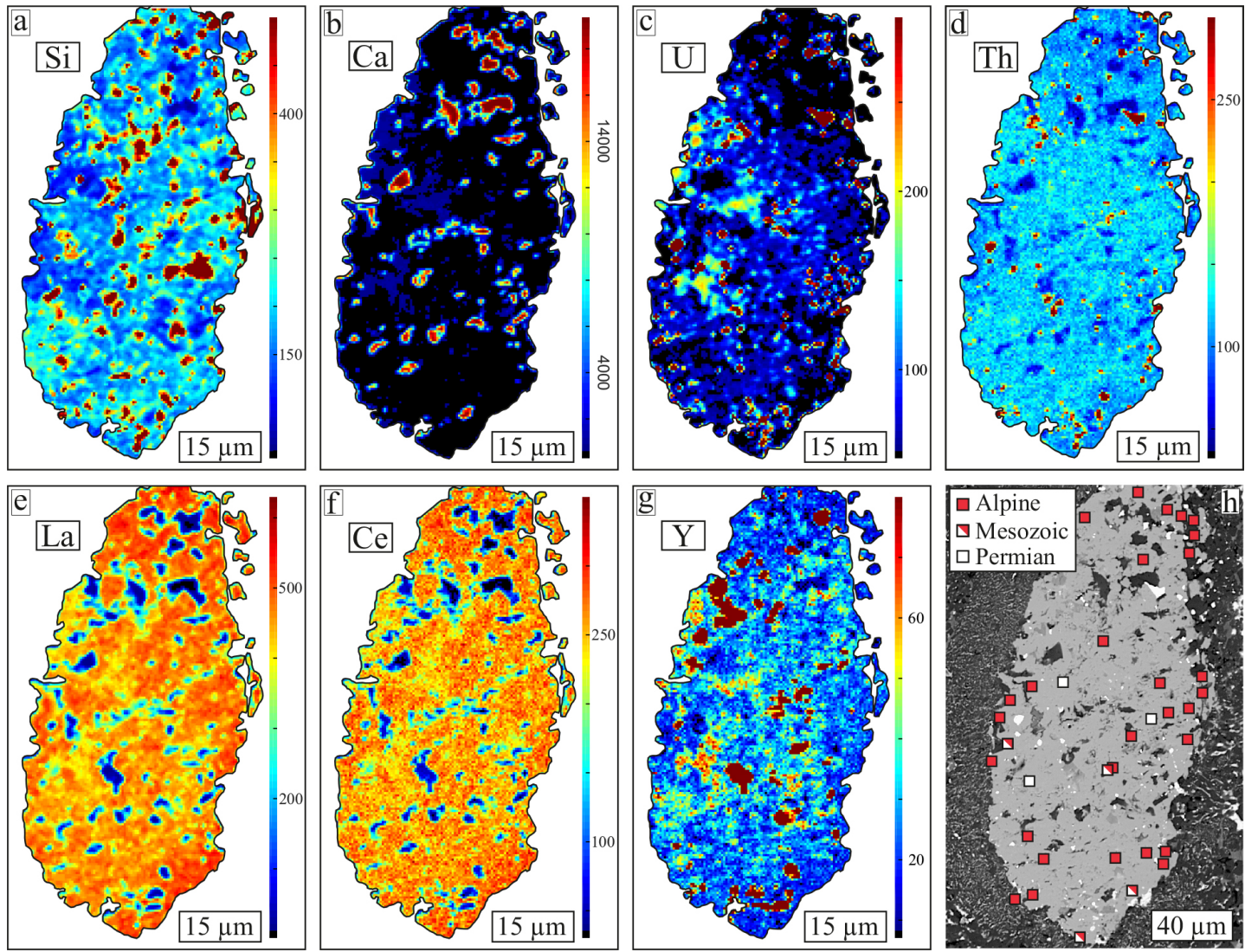

Figure 5. (a-g) Semi-quantitative element distribution maps for the monazite core from sample FH27 (unit: counts; compare Fig. 2f). (h) BSE image showing measurement points for EMP dating.

Table 3. Representative fluorapatite analyses (left: wt. \%; right: apfu) obtained by EMP (n.d.: not determined; b.d.l.: below detection limit).

\begin{tabular}{|c|c|c|c|c|c|c|c|c|c|c|c|}
\hline & FH27mon & FH21mon & FH21xen & FH21matrix & FH27matrix & & FH27mon & FH21mon & FH21xen & FH21matrix & FH27matrix \\
\hline $\mathrm{P}_{2} \mathrm{O}_{5}$ & 40.48 & 42.81 & 41.64 & 42.99 & 40.97 & $\mathrm{P}^{5+}$ & 2.931 & 3.000 & 2.964 & 3.005 & 3.008 \\
\hline $\mathrm{SiO}_{2}$ & 0.15 & 0.11 & 0.41 & b.d.l. & 0.07 & $\mathrm{Si}^{4+}$ & 0.013 & 0.009 & 0.035 & 0.000 & 0.006 \\
\hline $\mathrm{ThO}_{2}$ & b.d.l. & 0.04 & 0.05 & b.d.1. & b.d.1. & $\mathrm{Th}^{4+}$ & 0.000 & 0.001 & 0.001 & 0.000 & 0.000 \\
\hline $\mathrm{La}_{2} \mathrm{O}_{3}$ & b.d.1. & n.d. & n.d. & n.d. & b.d.1. & $\mathrm{La}^{3+}$ & 0.001 & n.d. & n.d. & n.d. & 0.000 \\
\hline $\mathrm{Ce}_{2} \mathrm{O}_{3}$ & 0.10 & 0.11 & b.d.l. & b.d.1. & b.d.1. & $\mathrm{Ce}^{3+}$ & 0.003 & 0.003 & 0.000 & 0.000 & 0.001 \\
\hline $\mathrm{Pr}_{2} \mathrm{O}_{3}$ & n.d. & b.d.1. & b.d.1. & b.d.1. & n.d. & $\mathrm{Pr}^{3+}$ & n.d. & 0.000 & 0.000 & 0.000 & n.d. \\
\hline $\mathrm{SrO}$ & 0.17 & 0.05 & b.d.1. & 0.04 & 0.28 & $\mathrm{Sr}^{2+}$ & 0.008 & 0.002 & 0.000 & 0.002 & 0.014 \\
\hline $\mathrm{FeO}$ & 0.13 & 0.04 & 0.15 & b.d.1. & 0.04 & $\mathrm{Fe}^{2+}$ & 0.009 & 0.002 & 0.011 & 0.000 & 0.003 \\
\hline $\mathrm{Na}_{2} \mathrm{O}$ & n.d. & 0.07 & 0.06 & b.d.1. & n.d. & $\mathrm{Na}^{+}$ & n.d. & 0.011 & 0.010 & 0.000 & n.d. \\
\hline F & 4.21 & 4.41 & 3.08 & 3.82 & 3.42 & $\mathrm{~F}$ & 1.140 & 1.155 & 0.820 & 0.996 & 0.937 \\
\hline $\mathrm{Cl}$ & b.d.l. & b.d.1. & b.d.l. & b.d.1. & b.d.l. & $\mathrm{Cl}$ & - & - & - & - & - \\
\hline Total & 100.36 & 101.88 & 101.10 & 101.79 & 98.39 & $\Sigma$ & 9.140 & 9.142 & 8.826 & 8.987 & 8.937 \\
\hline
\end{tabular}

$\mathrm{Y}+\mathrm{REE}+\mathrm{Th}+\mathrm{U})$ and allanite/epidote of lower REE contents (XAln <0.6). This gap is much wider in FH27 (with XAln $=0.95-1.0$ and XAln $<0.4$, respectively). The composition of allanite in other coronae, in which no monazite is visible, occupies the whole compositional range of the allanite fraction from $0 \%$ to $100 \%$ in the epidote-group mineral
(Fig. 8a). Therefore, we chose not to distinguish between an allanite zone and a separate epidote zone. Allanite/epidote grains are usually also zoned internally as well, with both normal (REE-rich to poor) and inverse zoning (Fig. 9). Compositional zoning can also be patchy. Epidote-group minerals that occur in the matrix of samples FH21 and FH27 have low 

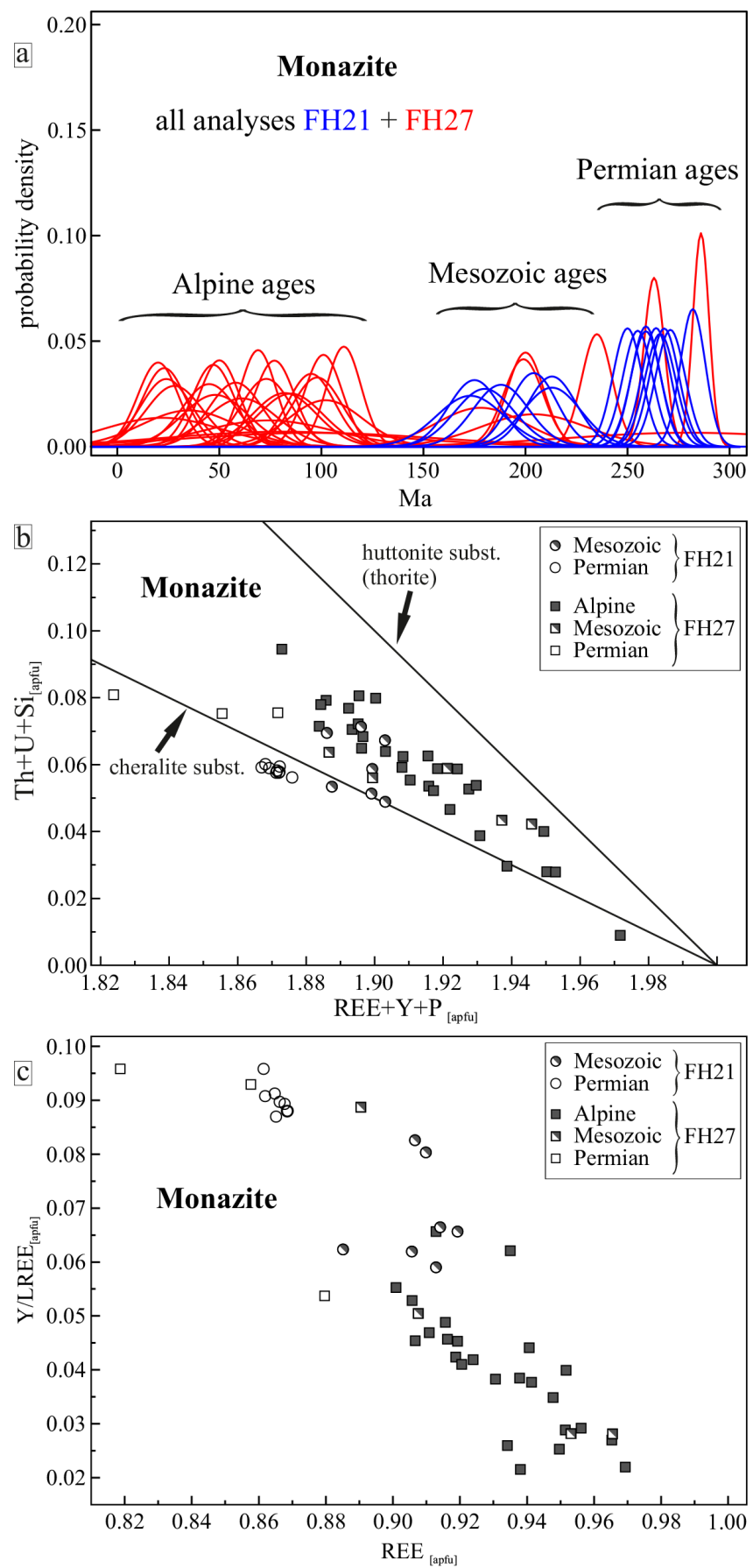

Figure 6. (a) Age distribution diagram for monazite from both FH21 and FH27. (b) Substitution diagram showing the composition of monazite from the two coronae. The two lines represent two substitutions towards the endmembers cheralite: $\mathrm{Ca}+(\mathrm{Th}, \mathrm{U})=2 \mathrm{REE}$ and huttonite: $\mathrm{Si}+(\mathrm{Th}, \mathrm{U})=\mathrm{REE}+\mathrm{P}$. (c) REE composition of monazite.
REE contents between 0.2 apfu and varying HREE/LREE ratios (Fig. 8a).

\subsection{Coronae around xenotime}

Xenotime is not as common as monazite, but, when present, it shows similar corona structures with an inner rim of fluorapatite and an outer rim of HREE-bearing epidote-group minerals (Fig. 10). In sample FH21, small zircon grains and U-bearing thorite can occur in the xenotime core (Fig. 10ad). Thorite occurs at the rim of voids in xenotime with negative crystal shape (Fig. 10d).

The fluorapatite grains, surrounding the xenotime, have an equant, polygonal shape and a size of $5-15 \mu \mathrm{m}$. They have a uniform Y+REE content of 0.026 to $0.038 \mathrm{apfu}$, which is mostly $\mathrm{Y}$, and negligible LREE, compared to fluorapatite in the monazite corona. In sample FH21 the fluorapatite is surrounded by a slightly zoned, semi-euhedral epidote crystal (Fig. 10b) with minor REE contents (Fig. 8, up to 0.07 apfu Gd and 0.1 apfu Y).

All EMP measurements were obtained from the corona from sample FH21 and are shown in Fig. 10b, c, d. The composition of xenotime is shown in Table 4. It incorporates less Th but significant $\mathrm{U}$ contents, with lower $\mathrm{Th} / \mathrm{U}$, compared to the monazite. The EMP age distribution for xenotime is shown in Fig. 11a. The six measurements can be grouped into Permian $280-290 \mathrm{Ma}(287 \pm 4 \mathrm{Ma})$ ages and younger Mesozoic $180-230 \mathrm{Ma}(205 \pm 20 \mathrm{Ma})$ ages, which are similar to the monazite measurements from FH21. The Permian-aged xenotime composition is interpreted as the primary magmatic composition (Xen1), which tends to have a higher Th/U ratio compared to the measurements with a Mesozoic age interpreted as altered metamorphic composition (Xen2; Fig. 11b). Yet, domains of a distinct difference in composition, beyond the chemical discrimination in age according to Eq. (1), are not evident (as opposed to monazite).

\subsection{Crystallographic relationships}

In the corona from sample FH21, EBSD measurements were collected from monazite, xenotime and fluorapatite in order to investigate possible orientation relationships between the minerals within the corona, especially between fluorapatite and monazite/xenotime. To avoid major artefacts from misindexing, we manually collected a set of point measurements, allowing the focus to be adjusted for every single measurement. Attention was paid to an unbiased distribution of points. The EBSD measurement locations and pole figures showing the orientation of monazite and fluorapatite from the FH21 corona are shown in Fig. 12.

The monazite has a uniform orientation, as have the small isolated islands of monazite (cf. Fig. 12a, 4h). The $c$ axes of the fluorapatite crystals scatter around the $b$ axis of the monazite crystal. The crystallographic orientation of both xenotime and fluorapatite is shown in Fig. 13. Fluorapatite $c$ axes 

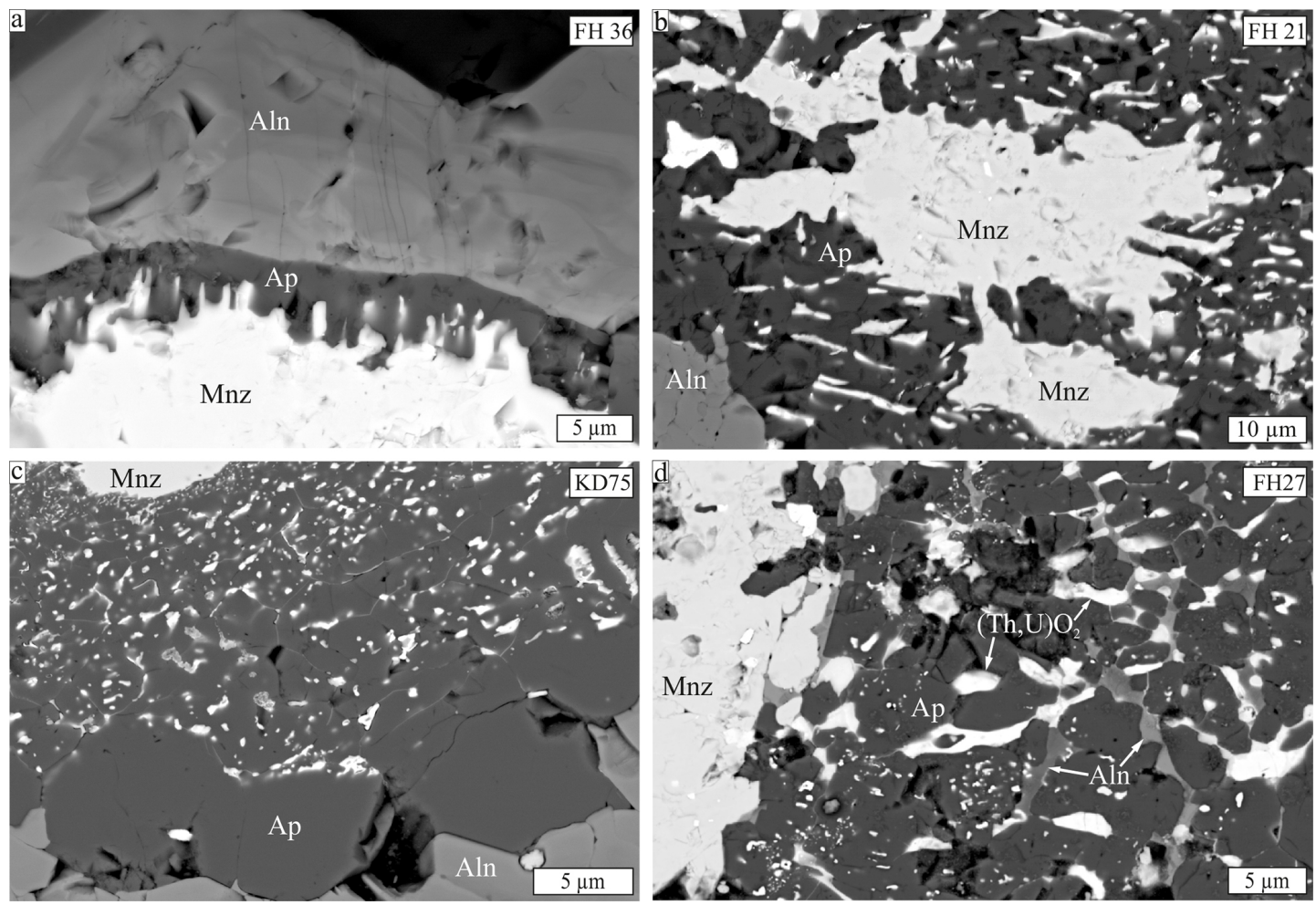

Figure 7. BSE images of the fluorapatite zone. (a) Thin fluorapatite zone around monazite of corona in sample FH36. Note serrated monazite interface to fluorapatite as opposed to straight zone boundary between fluorapatite and allanite. (b) Monazite relics in fluorapatite zone in sample FH21 (compare Fig. 4h). (c) The fluorapatite zone of the corona from sample KD75 (compare Fig. 2b). Note the increasing grain size from the monazite towards the allanite zone and the small grains of thorite and allanite. (d) The innermost part of the fluorapatite zone in the corona from FH27 (compare Fig. 2f). Note that the innermost part of the fluorapatite zone with intergrown thorite resembles a symplectic structure.
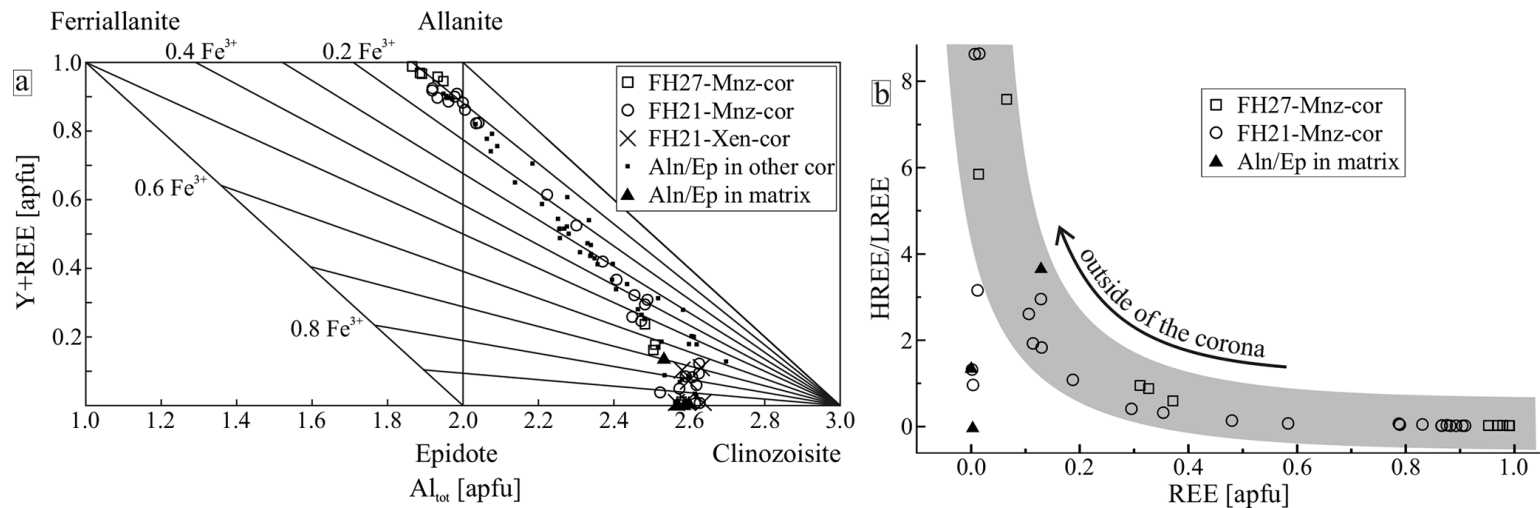

Figure 8. Chemical composition of REE-bearing epidote-group minerals. (a) REE +Y vs. Al tot diagram (following Petrík et al., 1995) and (b) in a REE-composition diagram. The data for grains from other coronae come from the samples listed in Table 1. Similarly, epidote-group minerals from the pegmatite's matrix come from all five samples (Table 1; in the following we use the abbreviation cor for corona).

largely scatter around the $c$ axis of the xenotime single crystal.

\subsection{LA-ICP-MS U-Th-Pb dating of allanite}

In the monazite corona of sample FH27, allanite was dated by LA-ICP-MS (Fig. 14). The common $\mathrm{Pb}$ fractions are relatively high $\left(f_{206}=0.86-0.97 ; f_{208}=0.86-0.99\right)$, requiring a common $\mathrm{Pb}$ correction. The uncorrected Tera-Wasserburg 

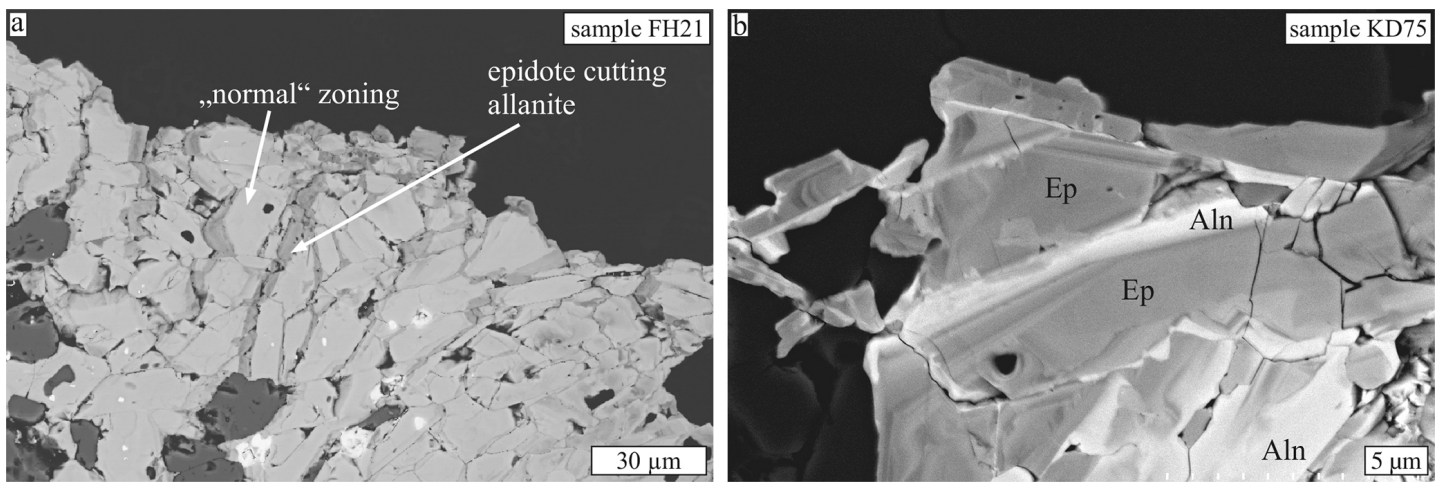

Figure 9. BSE images of the allanite/epidote zone in the coronae from FH27 (a) and KD75 (b), showing the shape and zoning (oscillatory and reverse) of epidote/allanite grains.
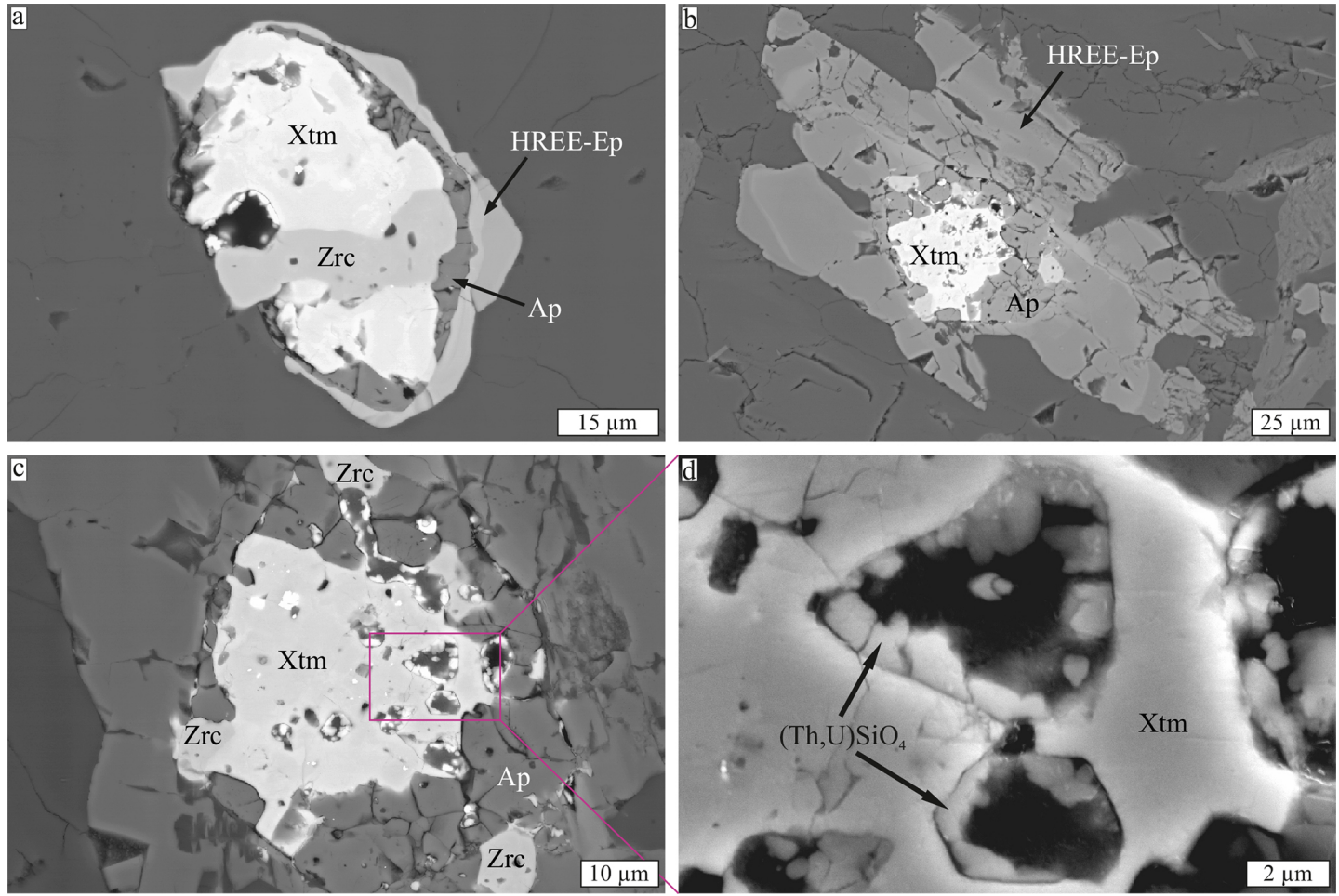

Figure 10. BSE images of coronae around xenotime from sample FH21. (a) Incipient replacement of a xenotime grain accompanied by zircon. (b) Corona on which the compositional measurements were done. (c) Close-up of the xenotime core from (b), also showing the polygonal fluorapatite grains. (d) Close-up of voids, which are partly filled with thorite at their edges.

diagram and the ${ }^{206} \mathrm{~Pb}$-corrected Th-isochron diagram are shown in Fig. 14a, b. The intercept age in the U-Pb system is $49 \pm 18 \mathrm{Ma}(2 \sigma, \mathrm{MSWD}=1.3 ; 10 / 13$ analyses $)$ and the Thisochron age is $69 \pm 14$. $(2 \sigma ; 10 / 13$ analyses $)$. The commonlead corrected ages (Fig. 14c, d) are 48.0 \pm 8 (2 $\sigma$, MSWD $=0.5 ; 10 / 13$ analyses $)$ and $58 \pm 6 \mathrm{Ma}(2 \sigma, \mathrm{MSWD}=0.16$; $10 / 13$ analyses) for the $\mathrm{U}-\mathrm{Pb}$ and $\mathrm{Th}-\mathrm{Pb}$ systems, respectively. Low values of MSWD in the corrected ages are caused by additional uncertainties deriving from the common-lead correction.

\section{Discussion}

\subsection{Age and formation of secondary monazite and xenotime}

We used two different approaches to date the minerals that form the coronae, i.e. monazite, xenotime and allanite. Monazite and xenotime were dated by EMP, whose high spatial resolution allows different growth domains and their ages to be to resolved within single crystal corona cores. The U-Th- 
Table 4. Representative allanite and xenotime analyses (top: wt. \%; bottom: apfu) obtained by EMP (n.d.: not determined; b.d.l.: below detection limit).

\begin{tabular}{|c|c|c|c|c|c|c|c|c|c|}
\hline \multicolumn{7}{|c|}{ Allanite/epidote } & \multicolumn{3}{|c|}{ Xenotime } \\
\hline \multirow{2}{*}{$\begin{array}{l}\text { Sample } \\
\text { type }\end{array}$} & \multicolumn{2}{|c|}{ FH21mon-cor } & \multicolumn{2}{|c|}{ FH27mon-cor } & \multirow{2}{*}{$\begin{array}{r}\text { FH21xen-cor } \\
\text { FH21xen }\end{array}$} & \multirow{2}{*}{$\begin{array}{c}\mathrm{FH} 21 \\
\text { matrix }\end{array}$} & & \multirow[b]{2}{*}{ FH21perm } & \multirow[b]{2}{*}{ FH21meso } \\
\hline & high REE & low REE & high REE & low REE & & & & & \\
\hline $\mathrm{SiO}_{2}$ & 31.02 & 38.81 & 31.54 & 37.85 & 38.16 & 37.82 & $\mathrm{P}_{2} \mathrm{O}_{5}$ & 35.05 & 35.55 \\
\hline $\mathrm{TiO}_{2}$ & 0.07 & b.d.l. & b.d.l. & b.d.l. & b.d.l. & 0.04 & $\mathrm{SiO}_{2}$ & 0.56 & 0.30 \\
\hline $\mathrm{Al}_{2} \mathrm{O}_{3}$ & 17.35 & 27.36 & 18.15 & 27.49 & 27.68 & 27.69 & $\mathrm{SO}_{3}$ & 0.02 & 0.02 \\
\hline $\mathrm{FeO}$ & 12.47 & 7.81 & 11.47 & 5.79 & 5.91 & 5.94 & $\mathrm{CaO}$ & 0.36 & 0.22 \\
\hline $\mathrm{MnO}$ & 0.16 & 0.11 & 0.24 & 0.19 & 0.15 & 0.10 & $\mathrm{ThO}_{2}$ & 0.59 & 0.23 \\
\hline $\mathrm{MgO}$ & 0.10 & b.d.l. & 0.15 & b.d.1. & b.d.l. & b.d.l. & $\mathrm{UO}_{2}$ & 2.48 & 1.38 \\
\hline $\mathrm{CaO}$ & 10.13 & 22.48 & 11.52 & 22.80 & 22.38 & 24.29 & $\mathrm{PbO}$ & 0.10 & 0.04 \\
\hline $\mathrm{Na}_{2} \mathrm{O}$ & b.d.l. & b.d.l. & n.d. & n.d. & b.d.1. & b.d.1. & $\mathrm{La}_{2} \mathrm{O}_{3}$ & n.d. & n.d. \\
\hline $\mathrm{SrO}$ & b.d.1. & b.d.l. & b.d.l. & b.d.l. & b.d.1. & b.d.l. & $\mathrm{Ce}_{2} \mathrm{O}_{3}$ & n.d. & n.d. \\
\hline $\mathrm{PbO}$ & b.d.l. & 0.04 & 0.07 & 0.09 & b.d.1. & b.d.l. & $\mathrm{Pr}_{2} \mathrm{O}_{3}$ & n.d. & n.d. \\
\hline $\mathrm{ThO}_{2}$ & 0.42 & b.d.l. & 1.10 & b.d.l. & b.d.1. & b.d.l. & $\mathrm{Nd}_{2} \mathrm{O}_{3}$ & 0.75 & 0.49 \\
\hline $\mathrm{UO}_{2}$ & b.d.1. & b.d.l. & b.d.l. & 0.08 & b.d.1. & b.d.l. & $\mathrm{Sm}_{2} \mathrm{O}_{3}$ & 1.27 & 1.21 \\
\hline $\mathrm{Y}_{2} \mathrm{O}_{3}$ & 0.13 & 0.59 & 0.28 & 1.47 & 2.20 & b.d.l. & $\mathrm{Eu}_{2} \mathrm{O}_{3}$ & b.d.1. & 0.03 \\
\hline $\mathrm{La}_{2} \mathrm{O}_{3}$ & 6.55 & b.d.l. & 5.68 & b.d.l. & b.d.1. & b.d.l. & $\mathrm{Y}_{2} \mathrm{O}_{3}$ & 40.43 & 41.66 \\
\hline $\mathrm{Ce}_{2} \mathrm{O}_{3}$ & 13.10 & 0.09 & 11.40 & b.d.1. & b.d.1. & b.d.l. & $\mathrm{Gd}_{2} \mathrm{O}_{3}$ & 3.87 & 3.95 \\
\hline $\mathrm{Pr}_{2} \mathrm{O}_{3}$ & 1.18 & b.d.l. & 1.27 & b.d.l. & b.d.1. & b.d.l. & $\mathrm{Dy}_{2} \mathrm{O}_{3}$ & 7.14 & 7.38 \\
\hline $\mathrm{Nd}_{2} \mathrm{O}_{3}$ & 3.44 & 0.07 & 3.46 & b.d.l. & b.d.1. & 0.05 & $\mathrm{Ho}_{2} \mathrm{O}_{3}$ & 0.92 & 0.90 \\
\hline $\mathrm{Sm}_{2} \mathrm{O}_{3}$ & 0.68 & 0.13 & 0.73 & 0.10 & b.d.l. & b.d.l. & $\mathrm{Er}_{2} \mathrm{O}_{3}$ & 2.85 & 2.90 \\
\hline $\mathrm{Gd}_{2} \mathrm{O}_{3}$ & 0.30 & 0.12 & 0.31 & 0.13 & 0.26 & b.d.l. & $\mathrm{Yb}_{2} \mathrm{O}_{3}$ & 1.75 & 1.76 \\
\hline $\mathrm{Dy}_{2} \mathrm{O}_{3}$ & b.d.l. & b.d.l. & n.d. & n.d. & b.d.l. & b.d.l. & $\mathrm{Lu}_{2} \mathrm{O}_{3}$ & 0.23 & 0.23 \\
\hline $\mathrm{Ho}_{2} \mathrm{O}_{3}$ & b.d.l. & b.d.l. & n.d. & n.d. & b.d.l. & b.d.l. & Total & 98.38 & 98.40 \\
\hline $\mathrm{Er}_{2} \mathrm{O}_{3}$ & b.d.1. & b.d.1. & n.d. & n.d. & b.d.1. & b.d.l. & & & \\
\hline Total & 97.10 & 97.61 & 97.37 & 95.99 & 96.74 & 95.89 & $\mathrm{P}^{5+}$ & 1.034 & 1.044 \\
\hline & & & & & & & $\mathrm{Si}^{4+}$ & 0.019 & 0.010 \\
\hline $\mathrm{Si}$ & 3.009 & 3.036 & 2.873 & 3.013 & 3.018 & 2.978 & $S^{6+}$ & 0.001 & 0.001 \\
\hline $\mathrm{Al}$ & 0.000 & 0.000 & 0.127 & 0.000 & 0.000 & 0.022 & $\mathrm{Ca}^{2+}$ & 0.013 & 0.008 \\
\hline$\Sigma \mathrm{T}$ & 3.009 & 3.036 & 3.000 & 3.013 & 3.018 & 3.000 & $\mathrm{Th}^{4+}$ & 0.005 & 0.002 \\
\hline $\mathrm{Ti}$ & 0.005 & - & - & - & - & 0.000 & $\mathrm{U}^{4+}$ & 0.019 & 0.011 \\
\hline $\mathrm{Fe}^{3+}$ & 0.010 & 0.000 & 0.000 & 0.000 & 0.000 & 0.000 & $\mathrm{~Pb}^{4+}$ & 0.001 & 0.000 \\
\hline $\mathrm{Al}$ & 0.985 & 1.000 & 0.736 & 0.977 & 0.973 & 0.948 & $\mathrm{La}^{3+}$ & n.d. & n.d. \\
\hline$\Sigma \mathrm{M} 1$ & 1.000 & 1.000 & 0.736 & 0.977 & 0.973 & 0.948 & $\mathrm{Ce}^{3+}$ & n.d. & n.d. \\
\hline $\mathrm{Al}$ & 1.000 & 1.000 & 1.000 & 1.000 & 1.000 & 1.000 & $\operatorname{Pr}^{3+}$ & n.d. & n.d. \\
\hline$\Sigma \mathrm{M} 2$ & 1.000 & 1.000 & 1.000 & 1.000 & 1.000 & 1.000 & $\mathrm{Nd}^{3+}$ & 0.009 & 0.006 \\
\hline $\mathrm{Al}$ & 0.000 & 0.522 & 0.086 & 0.602 & 0.608 & 0.600 & $\mathrm{Sm}^{3+}$ & 0.015 & 0.014 \\
\hline $\mathrm{Ti}$ & 0.000 & - & - & - & - & 0.002 & $\mathrm{Eu}^{3+}$ & - & 0.000 \\
\hline $\mathrm{Fe}^{3+}$ & 0.077 & 0.369 & 0.140 & 0.330 & 0.280 & 0.391 & $\mathrm{Y}^{3+}$ & 0.662 & 0.679 \\
\hline $\mathrm{Mg}$ & 0.014 & 0.002 & 0.020 & 0.000 & 0.000 & 0.000 & $\mathrm{Gd}^{3+}$ & 0.045 & 0.045 \\
\hline $\mathrm{Fe}^{2+}$ & 0.909 & 0.106 & 0.734 & 0.056 & 0.111 & 0.000 & $\mathrm{Dy}^{3+}$ & 0.080 & 0.082 \\
\hline $\mathrm{Mn}^{2+}$ & 0.000 & 0.000 & 0.018 & 0.013 & 0.000 & 0.007 & $\mathrm{Ho}^{3+}$ & 0.010 & 0.010 \\
\hline$\Sigma \mathrm{M} 3$ & 1.000 & 1.000 & 1.000 & 1.000 & 1.000 & 1.000 & $\mathrm{Er}^{3+}$ & 0.031 & 0.032 \\
\hline $\mathrm{Na}$ & - & - & - & - & - & - & $\mathrm{Yb}^{3+}$ & 0.019 & 0.019 \\
\hline $\mathrm{Ca}$ & 0.971 & 0.957 & 1.000 & 1.000 & 0.990 & 1.000 & $\mathrm{Lu}^{3+}$ & 0.002 & 0.002 \\
\hline $\mathrm{Mn} 2+$ & 0.014 & 0.007 & 0.000 & 0.000 & 0.010 & 0.000 & $\Sigma$ & 1.967 & 1.966 \\
\hline $\mathrm{Fe}^{2+}$ & 0.015 & 0.036 & 0.000 & 0.000 & 0.000 & 0.000 & & & \\
\hline$\Sigma \mathrm{A} 1$ & 1.000 & 1.000 & 1.000 & 1.000 & 1.000 & 1.000 & & & \\
\hline $\mathrm{Pb}$ & 0.001 & 0.001 & 0.002 & 0.002 & - & - & & & \\
\hline $\mathrm{Sr}$ & - & - & - & - & - & - & & & \\
\hline $\mathrm{Ca}$ & 0.081 & 0.927 & 0.124 & 0.944 & 0.907 & 1.049 & & & \\
\hline $\mathrm{Th}$ & 0.009 & - & 0.023 & - & - & - & & & \\
\hline $\mathrm{U}$ & 0.000 & 0.000 & 0.000 & 0.001 & - & - & & & \\
\hline $\mathrm{Y}+\mathrm{REE}$ & 0.900 & 0.037 & 1.115 & 0.062 & 0.102 & 0.003 & & & \\
\hline$\Sigma \mathrm{A} 2$ & 0.991 & 0.964 & 1.264 & 1.010 & 1.010 & 1.052 & & & \\
\hline
\end{tabular}



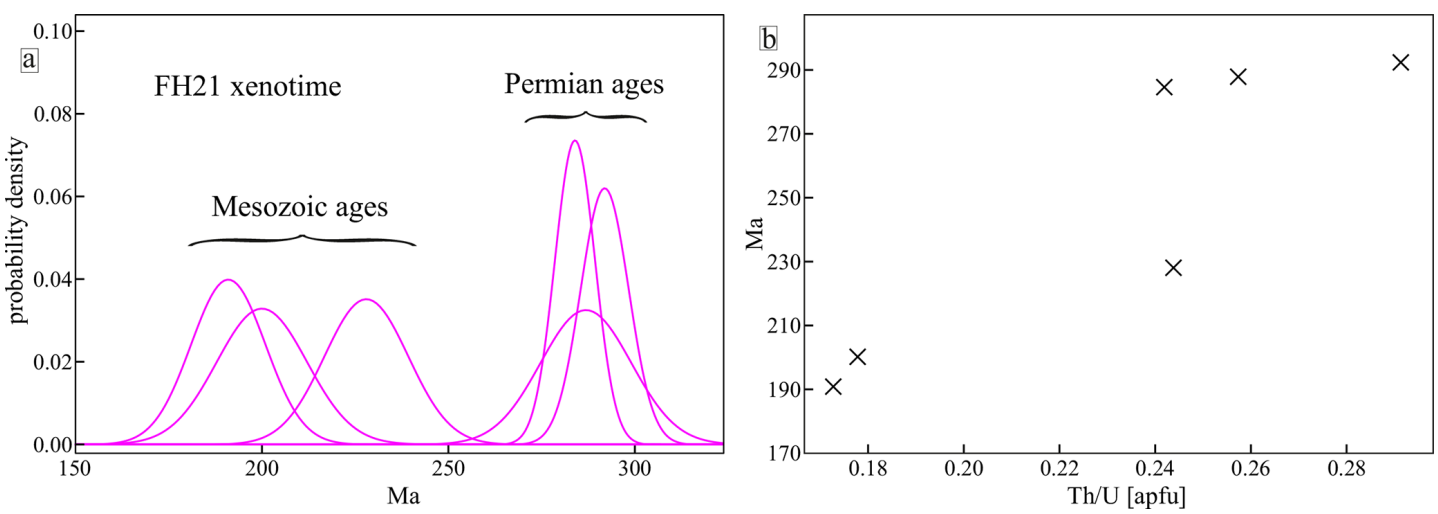

Figure 11. (a) Age distribution diagram for six measured xenotime points (pink curves) from sample FH21 (Fig. 10b, c). (b) Age vs. Th/U diagram of the same six measurement points.
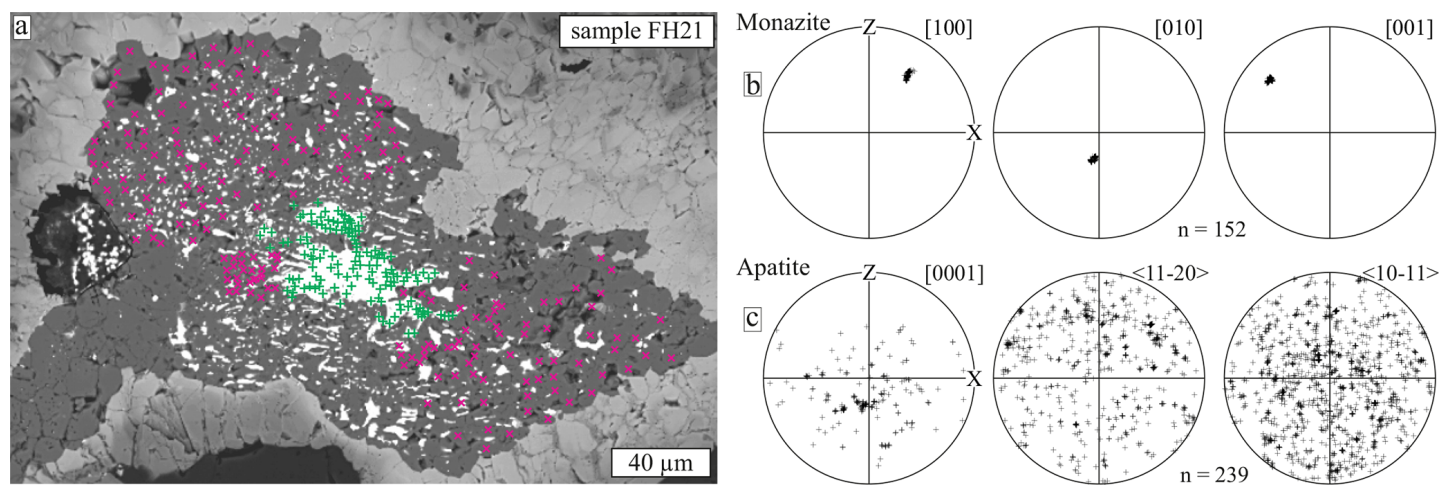

Figure 12. EBSD point measurements on fluorapatite and monazite. (a) BSE image showing the measurement locations: pink for fluorapatite and green for monazite. (b, c) Pole figures (equal angle projection of the lower hemisphere) for monazite (b) and fluorapatite (c).

$\mathrm{Pb}$ age of allanite in the corona was obtained by using LAICP-MS with a $24 \mu \mathrm{m}$ laser diameter.

Permian ages in the range of 250-290 Ma were found for primary monazite (Mnz1) and xenotime (Xen1) (Fig. 6a, 11a), consistent with the magmatic age reported for the pegmatites from this area (262 $\pm 7 \mathrm{Ma}$; Borsi et al., 1980; Knoll et al., 2018). Other compositions measured indicate younger ages and represent secondary monazite (Mnz2) or xenotime (Xen2) altered during metamorphism. The compositional changes accompanying the formation of secondary monazite in coronae are such that the altered domains (Mnz2) have less $\mathrm{Y}, \mathrm{Pb}, \mathrm{U}$, Th and $\mathrm{Ca}$ but are enriched in REE and $\mathrm{Si}$ compared to primary monazite Mnz1 (Figs. 4, 5, 6b, c; Table 2). Secondary monazite might have a lower or higher Th content than the primary monazite (Figs. 4, 5). Similar chemical changes were found in monazite alteration experiments by various authors (e.g. Budzyń et al., 2011, 2017; Grand'Homme et al., 2018). In all the samples, the crystallographic orientation of the primary and secondary monazite and xenotime is the same, which indicates crystallographic continuity during alteration. This crystallographic continuity is typical for interface-coupled dissolution-precipitation re- actions (Putnis, 2009) and has been observed in experiments on monazite (Harlov et al., 2011; Grand'Homme et al., 2018; Varga et al., 2020).

The alteration characteristics in the monazite coronae differ slightly. In the corona of sample FH21, primary and secondary monazite are separated into two domains, forming, essentially, a core-and-rim pattern (Fig. 4). Additionally, some satellite monazites occur as elongated islands in the fluorapatite zone (Fig. 4h). In the corona of sample FH27, secondary monazite is unevenly distributed, although dominantly occurring at the rim of the monazite (Fig. 5). Comparable structures, albeit on a smaller scale, have been found in alteration experiments on monazite, using $\mathrm{NaOH}$-rich fluids (Grand'Homme et al., 2016b, 2018). In these cases, the replacement proceeds along nanometre-sized channels, which result in a nano-scale mixture of unaltered and altered material. It is be possible that the microstructure found in sample FH27 resulted from alteration, in which the fluids travelled along irregular channels, rather than forming just a rim around the unaltered crystal, like that usually found for dissolution-precipitation processes (e.g. Putnis, 2009). The formation of chemically distinct domains was also found 

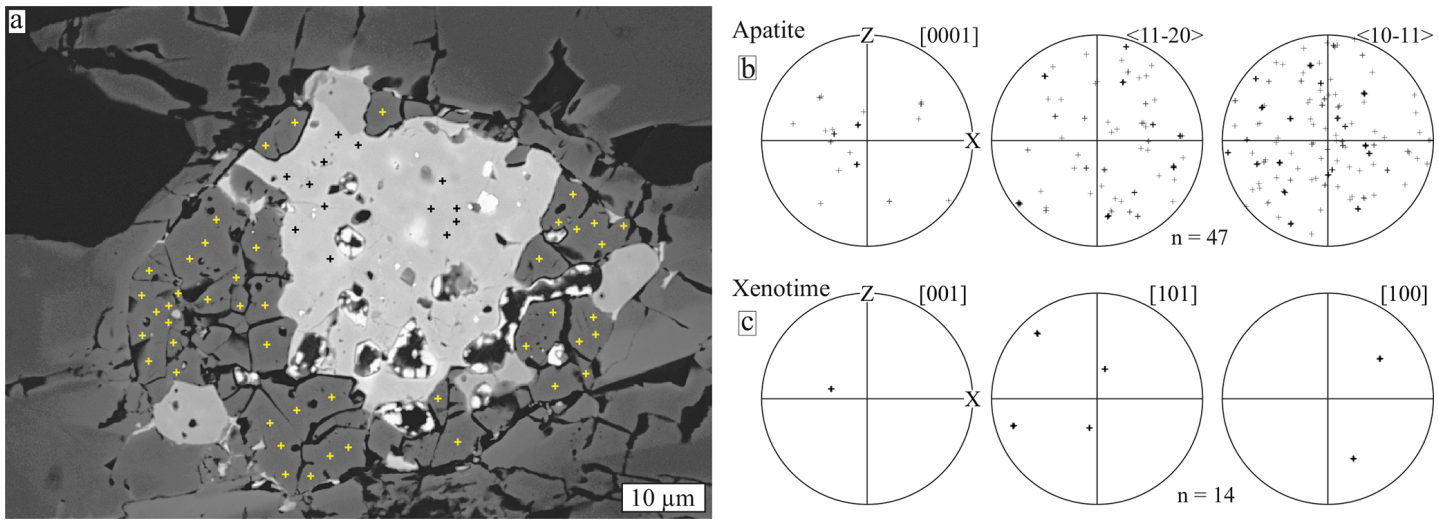

Figure 13. EBSD point measurements on fluorapatite and xenotime. (a) The measurement locations: yellow for fluorapatite and black for xenotime. (b, c) The pole figures (equal angle projection of the lower hemisphere) for fluorapatite (b) and xenotime (c).
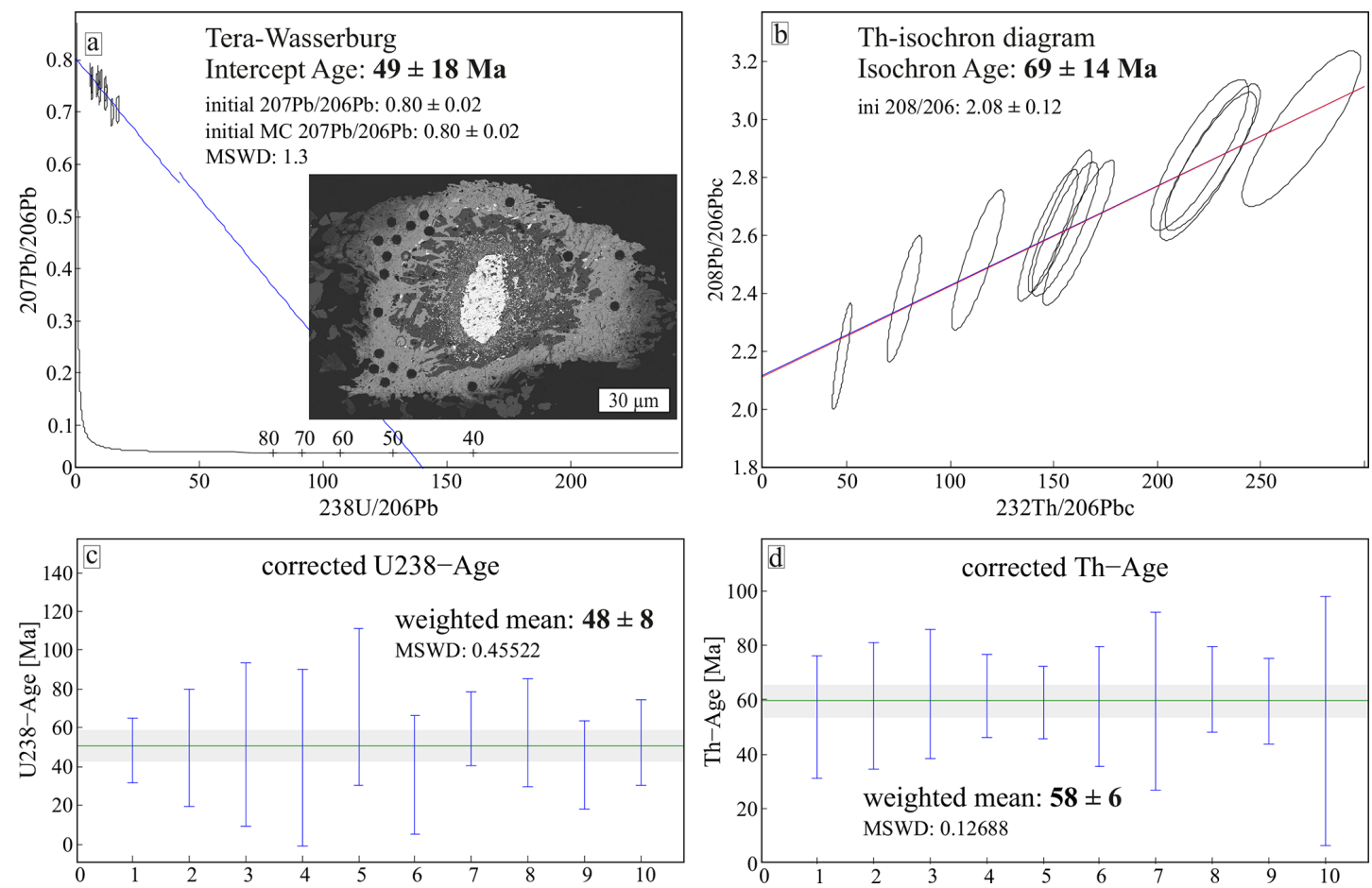

Figure 14. (a) Tera-Wasserburg and (b) Th-Pb-isochron diagram for allanite from sample FH27. (c, d) U and Th ages of the measurement points after correction for common $\mathrm{Pb}$.

in other alteration experiments (Seydoux-Guillaume et al., 2002; Budzyń et al., 2011, 2017). In the experiments of Budzyń et al. (2011; 2017), additionally, allanite and fluorapatite were produced, similar to the coronae described here (see below), although our dates are not precise enough to prove this temporal relationship. Also, these experiments showed a depletion of $\mathrm{Th}, \mathrm{Pb}, \mathrm{Ca}$ and $\mathrm{U}$ in the altered areas consistent with our observations.

$\mathrm{U}-\mathrm{Th}-\mathrm{Pb}$ redistribution in experimentally altered monazite is shown to depend on the reaction mechanisms (Seydoux-Guillaume et al., 2002; Harlov et al., 2011;
Grand'Homme et al., 2016b) and on physicochemical parameters (fluid speciation, fluid chemistry, temperature). The experiments showed that during metasomatism $\mathrm{Pb}$ can be completely removed from monazite, allowing us to date the metasomatic event (Budzyń et al., 2011; Harlov et al., 2011; Williams et al., 2011). However, naturally altered monazite can also show significant $\mathrm{Pb}$ concentrations (Bosse et al. 2008; Kelly et al., 2012; Didier et al., 2013; Skrzypek et al., 2020). Experimentally, Grand'Homme et al. (2016b, 2018) found that, although secondary monazite indeed contains no structural $\mathrm{Pb}$, primary unaltered monazite occurs together 
with secondary monazite in altered domains on the nanoscale due to incomplete replacement. This nanomixture is not resolvable by the spatial resolution of the EMP, which gives an intermediate age between primary and secondary monazite in the altered domain. As the fraction of primary monazite in the nanomixtures decreases with alteration temperature, higher temperatures lead to a more complete resetting of the U-Th-Pb system (Grand'Homme et al., 2016a, b).

The altered compositions for the corona in sample FH27 yield ages that are separated into two groups of $170-210 \mathrm{Ma}$ (Mesozoic) and 30-120 Ma (Alpine; Figs. 4, 5, 6a). The group of Alpine ages correlates to a specific chemical signature of higher REE and lower HREE/LREE contents compared to the Permian magmatic monazite, which has lower REE and higher HREE/LREE contents (Fig. 6b, c). The age of $60 \pm 10 \mathrm{Ma}$ obtained from allanite and interpreted as the age of corona formation falls into the Alpine age group. Overall, these secondary monazite compositions are interpreted to represent alteration during Alpine tectonometamorphism, with the possibility of nanomixture with primary monazite indicated by the large scatter of ages. We suggest that the monazite in the corona from sample FH21 does not preserve compositions with Alpine age, because of its more advanced replacement by fluorapatite during formation of the corona.

The significance of the Mesozoic age in both monazite and in xenotime ranging from 170 to $230 \mathrm{Ma}$ is difficult to interpret (Figs. 6a, 11a). This age group is not that clearly separated from the Permian age group (Fig. 6a) and the compositional signature is less specific, compared to the magmatic (lower REE; higher HREE/LREE) and the Alpine (higher REE; lower HREE/LREE) compositions (Fig. 6b, c). Therefore, it might rather represent a mixture of these two, indicating incomplete replacement during the Alpine orogeny. This is consistent with the observed inclusions and microporosity, which might indicate incomplete alteration (Grand'Homme, et al., 2016b). Although some indications of tectonometamorphic events in the Mesozoic exist (Castelli and Rubatto, 2002; Manzotti et al., 2012), it remains unclear, whether the Mesozoic age represents a discrete alteration event or a mixed primary and Alpine age.

\subsection{Monazite and xenotime breakdown reactions}

Monazite breakdown reactions into allanite-fluorapatite coronae have been described to happen during postmagmatic cooling (Broska et al., 2005; Petrík and Konečný, 2009), during prograde metamorphism from greenschistto-amphibolite-facies conditions (Broska and Siman, 1998; Finger et al., 1998), during retrograde metamorphism to greenschist-facies conditions (Lo Pò et al., 2016) and also during high-pressure metamorphism (Regis et al., 2012). Coronae around xenotime are much less frequently described (e.g. Broska, 2005). Experiments on the stability of monazite and xenotime at various $P-T$ conditions have shown that fluid composition plays a major role for their breakdown and the formation of the resulting product minerals (e.g. Seydoux-Guillaume et al., 2002; Harlov et al., 2011; Budzyń et al., 2011, 2015, 2017; Budzyń and Budzyń, 2015). The experiments by Budzyń et al. (2015), as well as Budzyń and Budzyń (2015), show that monazite and xenotime can be altered, with the formation of fluorapatite at low temperatures of $250-350{ }^{\circ} \mathrm{C}$ and with Ca-rich fluids stabilizing monazite and xenotime. However, no epidote formed under these conditions. The experiments of Budzyń et al. (2011) at $450-500^{\circ} \mathrm{C}$ and $450-610 \mathrm{MPa}$ document that the stability relations between monazite, fluorapatite, and allanite or REE epidote are more dependent on the fluid composition and the ratio of silicate minerals than on the $P-T$ conditions. Calcium-rich fluids produce fluorapatite and allanite, whereas $\mathrm{Na}$ - or even K-rich fluids may lead to the dissolution and the precipitation of new monazite but not allanite and fluorapatite (Budzyń et al., 2011, 2017; Grand'Homme et al., 2018). Thus, a high $\mathrm{Ca} / \mathrm{Na}$ ratio leads to the stabilization of allanite + fluorapatite relative to monazite. Fluids rich in $\mathrm{CO}_{2}$, apart from $\mathrm{F}$, may also lead to the formation of REE-rich carbonates, like hydroxylbastnäsite (Ondrejka et al., 2012). However, these experimental settings strongly deviate from the natural conditions in the pegmatites described here. Overall, the observed breakdown of monazite and xenotime to fluorapatite with allanite/epidote indicates alkali-bearing fluids with high $\mathrm{Ca} / \mathrm{Na}$ ratios as opposed to $\mathrm{KCl}$ - and $\mathrm{NaCl}$-rich or $\mathrm{CO}_{2}$-bearing fluids commonly thought to be present during metamorphism or partial melting (e.g. Hetherington and Harlov, 2008; Harlov et al., 2011; Budzyń et al., 2011, 2017). Consistently we assume the following generalized reactions:

$$
\begin{aligned}
& \text { Mnz1 + (Si, Ca, Al, Fe, F)fluid } \rightarrow \text { Mnz2 + LREE-Ap } \\
& \quad+\text { Aln/REE-Ep + (Th, U)SiO } \\
& \text { Xen1 + (Si, Ca, Al, Fe }) \text { fluid } \rightarrow \text { Xen2 + HREE-Ap } \\
& \quad+\text { HREE-Ep + Ep + (Th, U) } \mathrm{SiO}_{4} .
\end{aligned}
$$

Phosphorus from the monazite is directly incorporated into fluorapatite, Th and $\mathrm{U}$ are mostly captured in thorite, and the REE is mostly captured in allanite and to a much lesser extent in fluorapatite.

Finger et al. (1998) were able to perform mass balance calculations on similar corona structures around monazite and found that the coronae essentially represent diluted monazite, which means that most of the material from the original monazite did not escape the corona structure. Due to the non-circularity of the coronae observed here, uncertainties in the determination of the mineral fractions and perhaps the effects from non-central cutting, we were not able to perform the same mass balance calculations. But as the element distribution and microstructure of the coronae is similar to those for which such calculations were done (Finger et al., 1998; Upadhyay and Pruseth, 2012), it is likely that not much REE, $\mathrm{P}$, Th and $\mathrm{U}$ was lost from the corona into the surrounding mineral matrix, which is consistent with the different fluora- 
patite REE compositions inside the corona compared to outside in the mylonitic matrix.

In general, the $2 \mathrm{D}$ cross section of the $3 \mathrm{D}$ corona microstructure makes it difficult to assess the true proportions of the different mineral phases. Yet, as a first approximation, the relative proportions of fluorapatite to monazite within the images is taken as indication of the amount of replacement. The higher the relative proportions of fluorapatite to monazite, the higher the amount of monazite replacement by fluorapatite.

The observation that monazite inclusions in tourmaline are largely preserved (Fig. 3a, b), as opposed to being replaced by fluorapatite-allanite-epidote in the matrix (Fig. 3c-f), is most likely due to the fact that the tourmaline acts to largely shield the monazite from fluids present in the mineral matrix. This dependence of monazite replacement on the local surrounding microfabric indicates that the fluid availability along grain boundaries in the matrix and cracks controls the degree of reaction, by allowing the elementary mass transfer required for the corona development $(\mathrm{Ca}, \mathrm{Al}, \mathrm{Si}, \mathrm{Fe})$.

As discussed above, the presence of a fluid with a high $\mathrm{Ca} / \mathrm{Na}$ ratio is a prerequisite for the breakdown of monazite and xenotime; however, the source, availability and composition of the fluid remain difficult to assess. The question of an open or closed system is a matter of scale. Here, the rock matrix consists of pegmatite a few metres in size, which underwent metamorphic reactions and deformation in the presence of fluids during the Alpine orogeny (Stöckhert, 1987; Hofmann et al., 1983; Hentschel et al., 2019). Calcium-rich garnet grew at the expense of magmatic Ca-poor garnet, and the replacement of garnet by chlorite is only minor. Some Fe-bearing white mica, as well as biotite, formed partly at the expense of magmatic muscovite. Also, epidote grains formed along the mylonitic foliation. Feldspar alteration by sericite is comparatively weak. Plagioclase, which is, together with quartz, the main agent of the mylonitic deformation, deformed by a sequence of dislocation glide-controlled deformation associated with microfracturing followed by nucleation and growth involving dissolution-precipitation processes (Hentschel et al., 2019). These reactions and deformation processes provide strong evidence that fluids were present. Thus, the elements needed for corona formation ( $\mathrm{Si}, \mathrm{Ca}, \mathrm{Al}, \mathrm{Fe}$ and $\mathrm{F}$ ) were probably supplied during these metamorphic changes during deformation. The predominant source of $\mathrm{Ca}$ and $\mathrm{F}$ probably comes from the anorthite component in plagioclase and the micas, respectively (Hentschel et al., 2019). A major external source and/or fluid flow on a large scale is not necessary to explain the breakdown of monazite and xenotime, and, specifically, a fluid with a high $\mathrm{Ca} / \mathrm{Na}$ ratio as opposed to $\mathrm{KCl}$ - and $\mathrm{NaCl}$-rich or $\mathrm{CO}_{2}$ bearing fluids is indicated.

\subsection{Mechanism of corona formation}

The general structure of the monazite coronae - an almost pure fluorapatite zone surrounding the monazite core and an outer allanite-epidote zone - can be explained by different nucleation mechanisms. We suggest that monazite was partly dissolved along its phase boundary. The fluid became supersaturated with respect to fluorapatite, which precipitated immediately together with U-bearing thorite, forming the inner fluorapatite zone (Fig. $7 \mathrm{~b}, \mathrm{c}$ ). This process is referred to as interface-coupled dissolution-precipitation (Putnis, 2002, 2009; Putnis and Austrheim, 2010; Harlov et al., 2011), where dissolution of the original mineral phase, here monazite, and precipitation of the new mineral phase, here apatite, together with thorite are spatially coupled at the fluidinfiltrated interface of monazite. Small thorite grains occur also together with fluorapatite as inclusions in the replaced monazites (Fig. 3b). Hetherington and Harlov (2008) and Seydoux-Guillaume et al. (2012) also described thorite inclusions in altered xenotime and monazite in pegmatites from Norway that they interpreted as a direct result of interfacecoupled dissolution-precipitation, which was confirmed by the experiments of Harlov et al. (2011). Restricted transport of Th in the fluid phase compared to the REEs has also been observed in other corona structures (e.g. Broska et al., 2005; Ondrejka et al., 2012) and during the alteration of granites (Förster, 2000). Therefore, Th and U from the dissolving monazite are mostly immobilized by thorite precipitation and are only incorporated into the allanite or fluorapatite in smaller amounts.

Because of the weak structural similarity of apatite and monazite - both contain $\mathrm{PO}_{4}$ tetrahedra - precipitation occurred essentially at the reaction front to the dissolving monazite. The observed epitactic relationship between apatite and monazite, where the $c$ axes of the fluorapatite crystals scatter around the $b$ axis of the monazite crystal (Fig. 12), has also been described by Hansen and Harlov (2007). No systematic crystallographic relationships between apatite and xenotime, consistent with our observations (Fig. 13), have been reported up to now. Epitactic relations between products and reactants are also characteristic for symplectites, in which one mineral is replaced by two minerals closely intergrown with each other (e.g. Cahn, 1959; Abart et al., 2014). Indeed, the microstructure of the innermost fluorapatite zone with abundant U-bearing thorite inclusions resembles symplectic structures (Fig. 7b, c). The experiments of Spruzeniece et al. (2017) showed that similar structures could form via precipitation of a new phase within the pore space produced during dissolution of a product phase during interfacecoupled dissolution-precipitation.

Whereas apatite replaces monazite via interface-coupled dissolution-precipitation, allanite is precipitated after major material transport away from the reaction interface of the dissolving monazite at the outer rim of the corona (Fig. 15) The internal zoning of the allanite/epidote zone (Figs. 2b, d, 

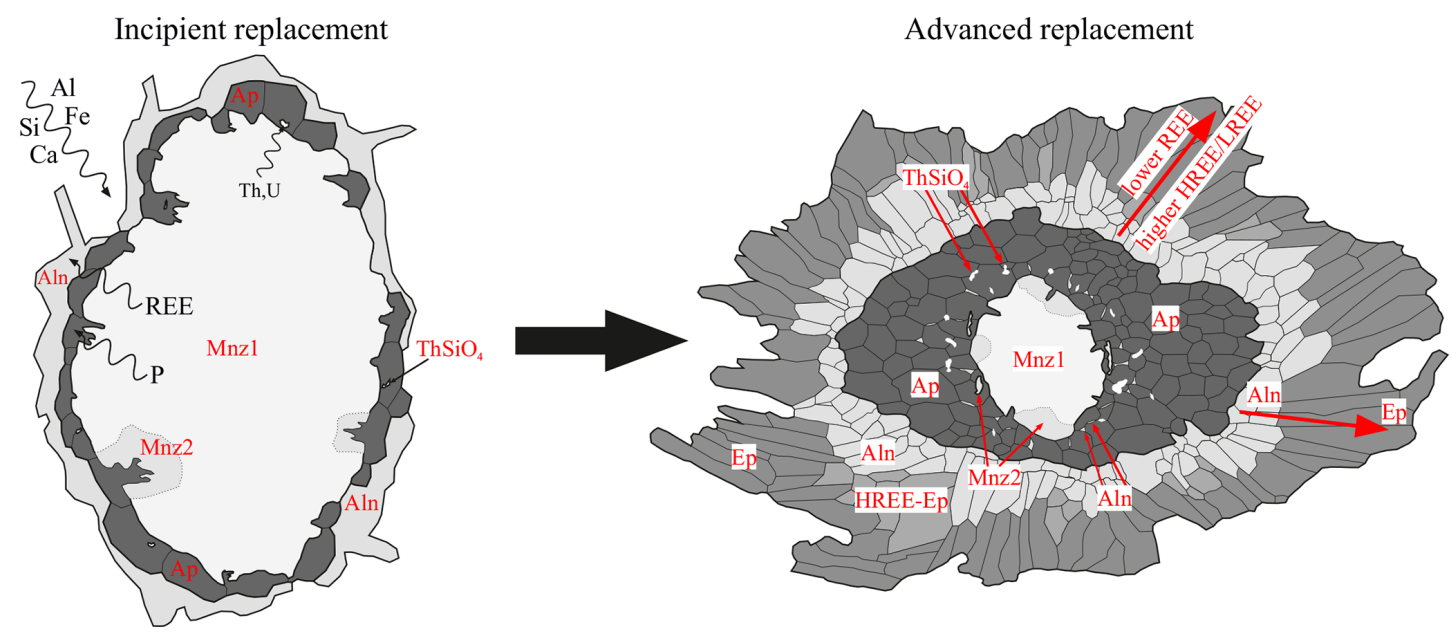

Figure 15. Sketch of observed corona microstructures with incipient and advanced replacement of monazite.

$\mathrm{e}, \mathrm{f}, 3 \mathrm{e}, \mathrm{f}, 9 \mathrm{~b})$ is difficult to explain. Although it has been reported that LREE allanite and HREE epidote nucleate separately (Finger et al., 1998; Upadhyay and Pruseth, 2012), full miscibility between epidote (without REE) and allanite $(\mathrm{Y}+\mathrm{REE}[\mathrm{apfu}]=1)$ is expected (Gieré and Sorensen, 2004; Armbruster et al., 2006). Experiments, which produce REE-bearing epidote minerals similar to the natural cases presented here, also suggest full miscibility (Budzyń et al., 2011, 2017). As the grains in our samples occupy the whole compositional range between epidote and allanite, our observations underpin full miscibility (Fig. 8). However, we observe here that allanite incorporates the LREE preferentially, as opposed to epidote that has a higher Y/LREE ratio, which has also been observed in other coronae (Finger et al., 1998). LREE allanite appears to precipitate closer to the replaced monazite, at greater distance in the outer rim; epidote forms at higher HREE/LREE ratios (Fig. 15). Consistently, xenotime is only replaced by Y-bearing fluorapatite and HREE epidote (Fig. 10). Changing HREE/LREE ratios have also been attributed to differential mobility of these elements in the fluid phase (e.g. Finger et al., 1998; Broska et al., 2005; Upadhyay and Pruseth, 2012). Also, differences in solubility can lead to different travel distances (e.g. Förster, 2000), which might have played a role for the observed REE zonation - higher HREE/LREE ratios towards the outside of the corona around monazite. This would suggest that the HREEs have a higher solubility than the LREEs in the fluid under the given conditions, which is consistent with the observation that altered monazite has a lower Y/LREE ratio than the magmatic monazite (Figs. 4, 5). A higher solubility of HREE compared to LREE has also been observed experimentally (Migdisov et al., 2009; Tropper et al., 2011, 2013). Nonetheless, more data on the solubility of REEs in such an environment consisting of rocks being deformed in the presence of fluids would be needed.
In addition to this radially changing REE composition, grains in the allanite/epidote zone can show oscillatory internal zonations and allanite overgrowths (Fig. 9). Oscillatory zoning does not necessarily reflect overall changes in fluid chemistry but might be caused by local equilibrium and self-organization (e.g. Wang and Marino, 1992; Borg et al., 2014). The preserved compositional gradients reflect the restricted mobilization of REE over limited distances, which is similarly observed in the experiments by Budzyń et al. (2011, 2017). Furthermore, fluorapatite and epidote in the coronae contain more REE than the same minerals in the mylonitic matrix do. Overall, the observed REE gradients in single grains, within the corona and on the thin-section scale suggest restricted transport through the fluid phase in relation to their solubility at the given temperature and fluid chemistry and/or episodic availability of fluids on the micron to millimetre scale.

\subsection{Relation between corona formation and deformation}

The relationship between the corona microstructure and the mylonitic microfabric can be used to infer their relative ages. The corona structures are aligned in the sample's foliation plane (Figs. 2 and 3). The fluorapatite and allanite/epidote zones mostly have a smaller width perpendicular and a larger width parallel to the foliation (Fig. 3). This geometry can mean that either (a) the replaced elongate monazite grains were rotated into the rock's foliation during deformation before corona formation or (b) the fluorapatite and allanite/epidote zones formed under non-isostatic stress conditions during deformation. The preserved monazite can even be elongate perpendicular to the foliation (Fig. 2f), with a smaller fluorapatite rim perpendicular to the foliation (Fig. 2d). This suggests that the replacement by fluorapatite was enhanced in the strain shadows of the monazite. There- 
fore, case (b) seems most likely. Yet, the outermost epidote zones themselves are mostly not deformed (Fig. 3e, f).

The mylonitic foliation is commonly deflected around the corona microstructure (Fig. 2a, c). Furthermore, the case of a corona around monazite situated in the prismatic strain shadow of a tourmaline, i.e. at a quartz-filled vein (Fig. 3c, d), indicates that the breakdown reactions of monazite to fluorapatite and allanite/epidote took place during formation of the mylonitic microfabric. These observations consistently suggest that the main stage of formation of the corona and the mylonitic foliation are more or less coeval, though the last growth of epidote took place locally during a late stage of deformation under already low stress conditions.

Overall, the corona formation and mylonitic deformation are interpreted to be interlinked and episodic processes. The inferred age of corona formation of $60 \pm 10$ Ma years, therefore, is also a time of active deformation in the area. $\mathrm{Rb}-\mathrm{Sr}$ muscovite cooling ages decrease from 250 to $30 \mathrm{Ma}$ from the DAV towards the north (Borsi et al., 1978). K-Ar muscovite cooling ages typically range between 100 and $60 \mathrm{Ma}$. $\mathrm{Rb}-\mathrm{Sr}$ and $\mathrm{K}-\mathrm{Ar}$ biotite cooling ages range between 30 and $15 \mathrm{Ma}$ (e.g. Steenken et al., 2002). This shows that, at the time of deformation and corona formation, the mylonitic pegmatites were at lower greenschist-facies conditions, which is quite consistent with the overall microfabric of the mylonitic pegmatites as well as the observed monazite/xenotime breakdown reactions. These data are also in line with constraints from the structurally similar main mylonite zone (MMZ), separating units of the upper Austroalpine of the DrauzugGurktal nappe system to the south from units of the KoralpeWölz nappe system to the north (Fig. 1), in the Kreuzeck Mountains southeast of the Tauern Window, where $\mathrm{Ar}-\mathrm{Ar}$ cooling ages of 87-81 Ma are interpreted as cooling ages subsequent to the thermal peak of Eoalpine metamorphism (Wölfler et al., 2015b). In the same area, zircon fission track ages of about $60 \mathrm{Ma}$ were, in combination with microstructural data, interpreted to indicate shear zone activity during greenschist-facies conditions (Wölfler et al., 2015a). Thus, in the eastern Austroalpine basement south of the western Tauern Window, the time between the Eoalpine (Cretaceous) tectonometamorphic event $\left(>100 \mathrm{Ma}, 450 \pm 50^{\circ} \mathrm{C}\right.$, $0.7 \mathrm{GPa}$, Stöckhert, 1984) and the final uplift and cooling in the Oligocene (30-33 Ma, Müller et al., 2000) was a tectonically active time of metamorphic reactions and deformation at lower greenschist-facies conditions.

\section{Conclusions and summary}

Analysis of the corona structures in the mylonitic pegmatites from the Austroalpine basement south of the western Tauern Window, which consist of an inner zone of fluorapatite, surrounding relict monazite and xenotime and an outer zone of allanite/REE-bearing epidote (Fig. 15) allows for the following conclusions to be drawn.
- Monocrystalline monazite and xenotime relics are heterogeneous in composition representing alteration via interface-coupled replacement reactions.

- EMP dating gives 250-287 Ma for compositional domains of both the monazite and xenotime, representing their primary composition, consistent with the magmatic age of the pegmatites.

- Ages in the range of 30-120 Ma are interpreted to represent monazite alteration during Alpine tectonometamorphism. LA-ICP-MS U/Th-Pb allanite ages of 50-60 Ma are interpreted as the age of corona formation.

- The chemical and structural characteristics of the coronae suggest that monazite and xenotime were dissolved in a fluid phase that provided the elements required for the precipitation of fluorapatite, allanite and epidote ( $\mathrm{Si}$, $\mathrm{Ca}, \mathrm{Al}, \mathrm{Fe}, \mathrm{F}$ ) derived from metamorphic reactions of the deforming pegmatites as opposed to large-scale fluid flow from external sources.

- The observed crystallographic relationship between fluorapatite and the replaced monazite and the highly irregular phase boundary indicate that fluorapatite directly replaced monazite via interface-controlled dissolutionprecipitation. The precipitation of allanite/epidote, however, was not controlled by the direct replacement of monazite/xenotime and occurred via REE transport through a fluid phase outside of the fluorapatite zone (Fig. 15).

- The relative amount of fluorapatite and relict monazite is dependent on the local surrounding microfabric (Figs. 2, 3), indicating that the fluid available along grain boundaries in the matrix and cracks controls the progression of monazite replacement.

- The preserved REE gradients in the single allanite/epidote grains within the corona and on the thinsection scale suggest restricted transport within the fluid phase and/or restricted availability of fluid as well as episodic reactions.

- The oblate shape of the coronae aligned within the sample's foliation and the deflection of the mylonitic foliation by the corona microstructure suggests that the replacement reactions took place during deformation. Thus, the time of corona formation at $\sim 60 \mathrm{Ma}$ was a time of metamorphic reactions at lower greenschistfacies conditions and deformation of the Austroalpine basement south of the western Tauern Window. 


\section{Appendix A}

Table A1. Electron microprobe measurement conditions used in this work.

\begin{tabular}{|c|c|c|c|c|c|c|c|}
\hline Element & Standard & Line & $\begin{array}{r}\text { Monazite } \\
15 \mathrm{kV}, 200 \mathrm{nA}\end{array}$ & $\begin{array}{r}\text { Allanite } \\
15 \mathrm{kV}, 20 \mathrm{nA}\end{array}$ & $\begin{array}{r}\text { Xenotime } \\
15 \mathrm{kV}, 200 \mathrm{nA}\end{array}$ & $\begin{array}{r}\text { Thorite } \\
15 \mathrm{kV}, 150 \mathrm{nA}\end{array}$ & $\begin{array}{l}\text { Fluorapatite } \\
15 \mathrm{kV}, 20 \mathrm{nA}\end{array}$ \\
\hline $\mathrm{Si}$ & Rhodonite & $\mathrm{K} \alpha$ & $240 \mathrm{~s}$ & $60 \mathrm{~s}$ & $160 / 240 \mathrm{~s}$ & $80 \mathrm{~s}$ & $60 \mathrm{~s}$ \\
\hline $\mathrm{Al}$ & $\mathrm{Y}_{3} \mathrm{Al}_{5} \mathrm{O}_{12}$ & $\mathrm{~K} \alpha$ & - & $60 \mathrm{~s}$ & - & - & - \\
\hline $\mathrm{Fe}$ & Hematite & $\mathrm{K} \alpha$ & - & $60 \mathrm{~s}$ & - & - & $60 \mathrm{~s}$ \\
\hline Mn & Rhodonite & $\mathrm{K} \alpha$ & - & $60 \mathrm{~s}$ & - & - & $80 \mathrm{~s}$ \\
\hline $\mathrm{Na}$ & Albite & $\mathrm{K} \alpha$ & - & - & - & - & $60 \mathrm{~s}$ \\
\hline $\mathrm{Ca}$ & Apatite & $\mathrm{K} \alpha$ & $60 s$ & $60 s$ & $120 \mathrm{~s}$ & $100 \mathrm{~s}$ & $40 \mathrm{~s}$ \\
\hline $\mathrm{P}$ & Apatite & $\mathrm{K} \alpha$ & $60 s$ & - & $40 / 20 \mathrm{~s}$ & $100 \mathrm{~s}$ & $40 \mathrm{~s}$ \\
\hline $\mathrm{F}$ & $\mathrm{CaF}_{2}$ & $\mathrm{~K} \alpha$ & - & - & - & - & $40 \mathrm{~s}$ \\
\hline$S$ & $\mathrm{ZnS}$ & $\mathrm{K} \alpha$ & $160 \mathrm{~s}$ & - & $120 \mathrm{~s}$ & - & $120 \mathrm{~s}$ \\
\hline $\mathrm{Cl}$ & Tugtupite & $\mathrm{K} \alpha$ & - & - & - & - & $80 \mathrm{~s}$ \\
\hline As & GaAs & $\mathrm{L} \alpha$ & $160 \mathrm{~s}$ & - & $160 \mathrm{~s}$ & - & $80 \mathrm{~s}$ \\
\hline $\mathrm{Mg}$ & $\mathrm{MgO}$ & $\mathrm{K} \alpha$ & - & $80 \mathrm{~s}$ & - & - & - \\
\hline $\mathrm{Sr}$ & Celestine & $\mathrm{L} \alpha$ & - & $100 \mathrm{~s}$ & - & - & $100 \mathrm{~s}$ \\
\hline $\mathrm{Ti}$ & $\mathrm{TiO}_{2}$ & $\mathrm{~K} \alpha$ & - & $80 \mathrm{~s}$ & - & - & - \\
\hline $\mathrm{Th}$ & $\mathrm{ThO}_{2}$ & $\mathrm{Ma}$ & $160 \mathrm{~s}$ & $100 \mathrm{~s}$ & $160 / 300 \mathrm{~s}$ & $20 \mathrm{~s}$ & $80 \mathrm{~s}$ \\
\hline $\mathrm{U}$ & $\mathrm{UO}_{2}$ & $\mathrm{M} \beta$ & $300 \mathrm{~s}$ & $100 \mathrm{~s}$ & $160 \mathrm{~s}$ & $20 \mathrm{~s}$ & $80 \mathrm{~s}$ \\
\hline $\mathrm{Pb}$ & Crocoite & $\mathrm{M} \beta$ & $480 \mathrm{~s}$ & $100 \mathrm{~s}$ & $360 / 480 \mathrm{~s}$ & $300 \mathrm{~s}$ & $80 \mathrm{~s}$ \\
\hline $\mathrm{Y}$ & $\mathrm{YPO}_{4}$ & $\mathrm{~L} \alpha$ & $160 \mathrm{~s}$ & $200 \mathrm{~s}$ & $40 / 20 \mathrm{~s}$ & $120 \mathrm{~s}$ & $120 \mathrm{~s}$ \\
\hline $\mathrm{La}$ & $\mathrm{LaPO}_{4}$ & $\mathrm{~L} \alpha$ & $350 \mathrm{~s}$ (EDS) & $80 \mathrm{~s}$ & - & - & $120 \mathrm{~s}$ \\
\hline $\mathrm{Ce}$ & $\mathrm{CePO}_{4}$ & $\mathrm{~L} \alpha$ & $350 \mathrm{~s}(\mathrm{EDS})$ & $80 s$ & - & $100 \mathrm{~s}$ & $100 \mathrm{~s}$ \\
\hline $\operatorname{Pr}$ & $\mathrm{PrPO}_{4}$ & $\mathrm{~L} \beta$ & $350 \mathrm{~s}(\mathrm{EDS})$ & $80 \mathrm{~s}$ & - & - & $100 \mathrm{~s}$ \\
\hline $\mathrm{Nd}$ & $\mathrm{NdPO}_{4}$ & $\mathrm{~L} \alpha$ & $350 \mathrm{~s}$ (EDS) & $80 s$ & $350 / 220 \mathrm{~s}(\mathrm{EDS})$ & - & $100 \mathrm{~s}$ \\
\hline $\mathrm{Sm}$ & $\mathrm{SmPO}_{4}$ & $\mathrm{~L} \beta$ & $350 \mathrm{~s}$ (EDS) & $80 s$ & $60 / 80 \mathrm{~s}$ & - & $100 \mathrm{~s}$ \\
\hline $\mathrm{Gd}$ & $\mathrm{GdPO}_{4}$ & $\mathrm{~L} \beta$ & $350 \mathrm{~s}$ (EDS) & $80 \mathrm{~s}$ & $60 / 80 \mathrm{~s}$ & $100 \mathrm{~s}$ & - \\
\hline Dy & $\mathrm{DyPO}_{4}$ & $\mathrm{~L} \alpha$ & - & - & $60 / 80 \mathrm{~s}$ & $100 \mathrm{~s}$ & - \\
\hline Ho & $\mathrm{HoPO}_{4}$ & $\mathrm{~L} \beta$ & - & - & $120 \mathrm{~s}$ & - & - \\
\hline $\mathrm{Er}$ & $\mathrm{ErPO}_{4}$ & $\mathrm{~L} \alpha$ & - & - & $60 / 80 \mathrm{~s}$ & - & - \\
\hline $\mathrm{Yb}$ & $\mathrm{YbPO}_{4}$ & $\mathrm{~L} \alpha$ & - & - & $60 / 80 \mathrm{~s}$ & - & - \\
\hline
\end{tabular}


Data availability. Further data will be made available upon request for scientific research purposes.

Supplement. The supplement related to this article is available online at: https://doi.org/10.5194/ejm-32-521-2020-supplement.

Author contributions. FH, EJ and CAT designed this study. The field work was done by FH. Microprobe dating of monazite and xenotime was done by VM, FH and EJ. PL performed the allanite dating. FH prepared the figures and the manuscript with contributions from EJ and CAT.

Competing interests. The authors declare that they have no conflict of interest.

Acknowledgements. The very constructive reviews by Daniel Harlov, Antonio Langone and two anonymous reviewers are gratefully acknowledged. We thank Sergey Krivovichev and Elena Belluso for the editorial handling of the manuscript and additional comments as well as Bernhard Stöckhert for discussions. Namvar Jahanmehr and Michael Herrmann are acknowledged for preparing thin sections, as are Patrick Eschenbacher and Dominique Mackensen for helping with field work.

Financial support. This research has been supported by the Deutsche Forschungsgemeinschaft (grant no. TR534-4-1).

Review statement. This paper was edited by Elena Belluso and reviewed by Daniel Harlov, Antonio Langone, and two anonymous referees.

\section{References}

Abart, R., Heuser, D., and Habler, G.: Mechanisms of myrmekite formation: case study from the Weinsberg granite, Moldanubian zone, Upper Austria, Contrib. Miner. Petrol., 168, 1-15, https://doi.org/10.1007/s00410-014-1074-7, 2014.

Armbruster, T., Bonazzi, P., Akasaka, M., Bermanec, V., Chopin, C., Gieré, R., Heuss-Assbichler, S., Liebscher, A., Menchetti, S., Pan, Y., and Pasero, M.: Recommended nomenclature of epidote-group minerals, Eur. J. Mineral., 2, 551-567, https://doi.org/10.1127/0935-1221/2006/0018-0551, 2006.

Bachmann, F., Hielscher, R., and Schaeben, H.: Texture Analysis with MTEX - Free and Open Source Software Toolbox, Solid State Phenomen., 160, 63-68, https://doi.org/10.4028/www.scientific.net/SSP.160.63, 2010.

Bea, F.: Residence of REE, Y, Th and U in granites and crustal protoliths; implications for the chemistry of crustal melts, J. Petrol., 37, 521-552, https://doi.org/10.1093/petrology/37.3.521, 1996.

Borg, S., Liu, W., Pearce, M., Cleverley, J., and MacRae, C.: Complex mineral zoning patterns caused by ultra-local equilibrium at reaction interfaces, Geology, 42, 415-418, https://doi.org/10.1130/G35287.1, 2014.

Borsi, S., Del Moro, A., Sassi, F. P., Zanferrari, A., and Zirpoli, G.: New geopetrologic and radiometric data on the Alpine history of the Austridic continental margin south of the Tauern window (Eastern Alps), Mem. di Sci. Geol., 32, 1-19, 1978.

Borsi, S., Del Moro, A., Sassi, F. P., Visona, D., and Zirpoli, G.: On the existence of Hercynian aplites and pegmatites in the lower Aurina valley (Ahrntal, Austrides, Eastern Alps), Neues Jb. Miner., 11, 501-514, 1980.

Bosse, V., Boulvais, P., Gautier, P., Devidal, J.-L., Cherneva, Z., Boulvais, P., Ruffet, G., Paquette, J.-L., Tiepolo, M., Bosse, V., and Gerdjikov, I.: Fluid-induced disturbance of the monazite Th$\mathrm{Pb}$ chronometer: In situ dating and element mapping in pegmatites from the Rhodope (Greece, Bulgaria), Chem. Geol., 261, 286-302, https://doi.org/10.1016/j.chemgeo.2008.10.025, 2008.

Broska, I. and Siman, P.: The breakdown of monazite in the WeszCarpathian Veporic orthogneisses and Tatric granites, Geol. Carpathica, 49, 161-167, 1998.

Broska, I., Williams, T. C., Janák, M., and Nagy, G.: Alteration and breakdown of xenotime-(Y) and monazite-(Ce) in granitic rocks of the Western Carpathians, Slovakia, Lithos, 82, 71-83, https://doi.org/10.1016/j.lithos.2004.12.007, 2005.

Budzyń, B. and Jastrzębski, M.: Monazite stability and the maintenance of Th-U-total $\mathrm{Pb}$ ages during post-magmatic processes in granitoids and host metasedimentary rocks: A case study from the Sudetes (SW Poland), Geol. Q., 60, 104-121, https://doi.org/10.7306/gq.1254, 2016.

Budzyń, B. and Kozub-Budzyń, G. A.: The stability of xenotime in high $\mathrm{Ca}$ and $\mathrm{Ca}-\mathrm{Na}$ systems, under experimental conditions of $250-350^{\circ} \mathrm{C}$ and $200-400 \mathrm{MPa}$ : The implications for fluidmediated low-temperature processes in granitic rocks, Geol. Q., 59, 316-324, https://doi.org/10.7306/gq.1223, 2015.

Budzyń, B., Harlov, D. E., Williams, M. L., and Jercinovic, M. J.: Experimental determination of stability relations between monazite, fluorapatite, allanite, and REE-epidote as a function of pressure, temperature, and fluid composition, Am. Mineral., 96, 1547-1567, https://doi.org/10.2138/am.2011.3741, 2011.

Budzyń, B., Harlov, D. E., Kozub-Budzyń, G. A., and Majka, J.: Experimental constraints on the relative stabilities of the two systems monazite-(Ce) - allanite-(Ce) - fluorapatite and xenotime-(Y) - (Y,HREE)-rich epidote - (Y,HREE)-rich fluorapatite, in high $\mathrm{Ca}$ and $\mathrm{Na}-\mathrm{Ca}$ environments under $P-T$ conditions of 200-1000, Mineral. Petrol., 111(2), 183-217, https://doi.org/10.1007/s00710-016-0464-0, 2017.

Burn, M., Lanari, P., Pettke, T., and Engi, M.: Non-matrix-matched standardisation in LA-ICP-MS analysis: General approach, and application to allanite $\mathrm{Th}-\mathrm{U}-\mathrm{Pb}$ dating, J. Anal. Atom. Spectrom., 32, 1359-1377, https://doi.org/10.1039/c7ja00095b, 2017.

Cahn, J. W.: The kinetics of cellular segregation reactions, Acta Metall., 7, 18-28, https://doi.org/10.1016/0001-6160(59)901646, 1959.

Castelli, D. and Rubatto, D.: Stability of Al- and F-rich titanite in metacarbonate: petrologic and isotopic constraints from a polymetamorphic eclogitic marble of the internal Sesia Zone (Western Alps), Contrib. Mineral. Petr., 142, 627-639, https://doi.org/10.1007/s00410-001-0317-6, 2002.

Didier, A., Bosse, V., Boulvais, P., Bouloton, J., Paquette, J.-L., Montel, J.-M., and Devidal, J.-L.: Disturbance versus preserva- 
tion of U-Th- $\mathrm{Pb}$ ages in monazite during fluid-rock interaction: Textural, chemical and isotopic in situ study in microgranites (Velay Dome, France), Contrib. Miner. Petrol., 165, 1051-1072, https://doi.org/10.1007/s00410-012-0847-0, 2013.

Engi, M.: Petrochronology Based on REE-Minerals: Monazite, Allanite, Xenotime, Rev. Mineral. Geochem., 83, 365-418, 2017.

Finger, F., Broska, I., Roberts, Malcolm, P., and Schermair, A.: Replacement of primary monazite by apatite-allanite-epidote coronas in an amphibolite facies granite gneiss from the eastern Alps, Am. Mineral., 83, 248-258, 1998.

Förster, H.-J.: The chemical composition of REE-Y-Th-U-rich minerals in peraluminous accessory granites of the ErzgebirgeFichtelgebirge region, Germany. Part I: The monazite-(Ce)Brabantite solid solution series, Am. Mineral., 83, 259-272, https://doi.org/10.2138/am-1998-3-409, 1998a.

Förster, H.-J.: The chemical composition of REE-Y-Th-U-rich minerals in peraluminous accessory granites of the ErzgebirgeFichtelgebirge region, Germany. Part II: Xenotime, Am. Mineral., 83, 1302-1315, https://doi.org/10.2138/am-1998-3-409, 1998b.

Förster, H.-J.: Cerite-(Ce) and Thorian Synchysite from the Niederbobritzsch Granite, Erzgebirge, Germany: implications for the differential mobility of the LREE and Th during alteration, Can. Mineral., 38, 67-79, 2000.

Gieré, R. and Sorensen, S. S.: Allanite and Other REE-Rich Epidote-Group Minerals, Rev. Mineral. Geochem., 56, 431-493, https://doi.org/10.2138/gsrmg.56.1.431, 2004.

Goswami-Banerjee, S. and Robyr, M.: Pressure and temperature conditions for crystallization of metamorphic allanite and monazite in metapelites: a case study from the Miyar Valley (high Himalayan Crystalline of Zanskar, NW India), J. Metamorph. Geol., 33, 535-556, https://doi.org/10.1111/jmg.12133, 2015.

Grand'Homme, A., Janots, E., Bosse, V., Seydoux-Guillaume, A.-M. and De Ascenção Guedes, R.: Interpretation of $\mathrm{U}-\mathrm{Th}-\mathrm{Pb}$ in-situ ages of hydrothermal monazite-(Ce) and xenotime-(Y): evidence from a large-scale regional study in clefts from the western alps, Miner. Petrol., 110, 787-807, https://doi.org/10.1007/s00710-016-0451-5, 2016a.

Grand'Homme, A., Janots, E., Seydoux-Guillaume, A.-M., Guillaume, D., Bosse, V., and Magnin, V.: Partial resetting of the $\mathrm{U}-\mathrm{Th}-\mathrm{Pb}$ systems in experimentally altered monazite: Nanoscale evidence of incomplete replacement, Geology, 44, 431-434, https://doi.org/10.1130/G37770.1, 2016b.

Grand'Homme, A., Janots, E., Seydoux-Guillaume, A.-M., Guillaume, D., Magnin, V., Hövelmann, J., Höschen, C., and Boiron, M. C.: Mass transport and fractionation during monazite alteration by anisotropic replacement, Chem. Geol., 484, 51-68, https://doi.org/10.1016/j.chemgeo.2017.10.008, 2018.

Gregory, C. J., Rubatto, D., Allen, C. M., Williams, I. S., Hermann, J., and Ireland, T.: Allanite micro-geochronology: A LA-ICPMS and SHRIMP U-Th-Pb study, Chem. Geol., 245, 162-182, https://doi.org/10.1016/j.chemgeo.2007.07.029, 2007.

Habler, G., Thöni, M., and Grasemann, B.: Cretaceous metamorphism in the Austroalpine Matsch Unit (Eastern Alps): The interrelation between deformation and chemical equilibration processes, Miner. Petrol., 97, 149-171, https://doi.org/10.1007/s00710-009-0094-x, 2009.

Hansen, E. C. and Harlov, D. E.: Whole-rock, phosphate, and silicate compositional trends across an amphibolite- to granulite- facies transition, Tamil Nadu, India, J. Petrol., 48, 1641-1680, https://doi.org/10.1093/petrology/egm031, 2007.

Harlov, D. E., Wirth, R., and Hetherington, C. J.: Fluidmediated partial alteration in monazite?: the role of coupled dissolution-reprecipitation in element redistribution and mass transfer, Contrib. Mineral. Petr., 162, 329-348, https://doi.org/10.1007/s00410-010-0599-7, 2011.

Hentschel, F., Trepmann, C. A., and Janots, E.: Deformation of feldspar at greenschist facies conditions - the record of mylonitic pegmatites from the Pfunderer Mountains, Eastern Alps, Solid Earth, 10, 95-116, https://doi.org/10.5194/se-10-95-2019, 2019.

Hetherington, C. J. and Harlov, D. E.: Metasomatic thorite and uraninite inclusions in xenotime and monazite from granitic pegmatites, Hidra anorthosite massif, southwestern Norway: Mechanics and fluid chemistry, Am. Mineral., 93, 806-820, https://doi.org/10.2138/am.2008.2635, 2008.

Hofmann, K. H., Kleinschrodt, R., Lippert, R., Mager, D., and Stöckhert, B.: Geologische Karte des Altkristallins südlich des Tauernfensters zwischen Pfunderer Tal und Tauferer Tal (Südtirol), Der Schlern, 57, 572-590, 1983.

Janots, E., Engi, M., Berger, A., Allaz, J., Schwarz, J.-O., and Spandler, C.: Prograde metamorphic sequence of REE minerals in pelitic rocks of the Central Alps: implications for allanitemonazite-xenotime phase relations from 250 to $610^{\circ} \mathrm{C}$, J. Metamorph. Geol., 26, 509-526, https://doi.org/10.1111/j.15251314.2008.00774.x, 2008.

Kelly, N. M., Harley, S. L., and Möller, A.: Complexity in the behavior and recrystallization of monazite during high-T metamorphism and fluid infiltration, Chem. Geol., 322-323, 192-208, https://doi.org/10.1016/j.chemgeo.2012.07.001, 2012.

Kleinschrodt, R.: Quarzkorngefügeanalyse im Altkristallin südlich des westlichen Tauernfensters (Südtirol_Italien), Erlanger Geol. Abhandlungen, 114, 1-82, 1987.

Knoll, T., Schuster, R., Huet, B., Mali, H., Onuk, P., Horschinegg, M., Ertl, A., and Giester, G.: Spodumene pegmatites and related leucogranites from the austroalpine unit (eastern alps, central europe): Field relations, petrography, geochemistry, and geochronology, Can. Mineral., 56, 489-528, https://doi.org/10.3749/canmin.1700092, 2018.

Lo Pò, D., Braga, R., Massonne, H.-J., Molli, G., Montanini, A., and Theye, T.: Fluid-induced breakdown of monazite in medium-grade metasedimentary rocks of the Pontremoli basement (Northern Apennines, Italy), J. Metamorph. Geol., 34, 6384, https://doi.org/10.1111/jmg.12171, 2016.

Majka, J. and Budzyń, B.: Monazite breakdown in metapelites from Wedel Jarlsberg Land, Svalbard - preliminary report, Mineral. Pol., 37, 61-69, 2006.

Mancktelow, N. S., Stöckli, D., Grollimund, B., Müller, W., Fügenschuh, B., Viola, G., Seward, D., and Villa, I. M.: The DAV and Periadriatic fault systems in the Eastern Alps south of the Tauern window, Int. J. Earth Sci., 90, 593-622, https://doi.org/10.1007/s005310000190, 2001.

Manzotti, P., Rubatto, D., Darling, J., Zucali, M., Cenki-Tok, B., and Engi, M.: From Permo-Triassic lithospheric thinning to Jurassic rifting at the Adriatic margin: Petrological and geochronological record in Valtournenche (Western Italian Alps), Lithos, 146-147, 276-292, https://doi.org/10.1016/j.lithos.2012.05.007, 2012.

Migdisov, A. A., Williams-jones, A. E. and Wagner, T.: An experimental study of the solubility and speciation of the Rare Earth 
Elements ( III ) in fluoride- and chloride-bearing aqueous solutions at temperatures up to $300^{\circ} \mathrm{C}$, Geochim. Cosmochim. Acta, 73(23), 7087-7109, https://doi.org/10.1016/j.gca.2009.08.023, 2009.

Montel, J.-M., Michèle Veschambre, S. F., Nicollet, C., and Provost, A.: Electron-microprobe dating of monazite: The story, Chem. Geol., 131, 37-53, https://doi.org/10.1016/j.chemgeo.2017.11.001, 1996.

Müller, W., Mancktelow, N. S., and Meier, M.: Rb-Sr microchrons of synkinematic mica in mylonites: an example from the DAV fault of the Eastern Alps, Earth Planet. Sci. Lett., 180, 385-397, 2000.

Ondrejka, M., Uher, P., Putiš, M., Broska, I., Bačík, P., Konečný, P., and Schmiedt, I.: Two-stage breakdown of monazite by postmagmatic and metamorphic fluids: An example from the Veporic orthogneiss, Western Carpathians, Slovakia, Lithos, 142-143, 245-255, https://doi.org/10.1016/j.lithos.2012.03.012, 2012.

Ondrejka, M., Putiš, M., Uher, P., Schmiedt, I., Pukančik, L., and Konečný, P.: Fluid-driven destabilization of REE-bearing accessory minerals in the granitic orthogneisses of North Veporic basement (Western Carpathians, Slovakia), Miner. Petrol., 1-20, https://doi.org/10.1007/s00710-016-0432-8, 2016.

Petrík, I. and Konečný, P.: Metasomatic replacement of inherited metamorphic monazite in a biotite-garnet granite from the Nízke Tatry Mountains, Western Carpathians, Slovakia: Chemical dating and evidence for disequilibrium melting, Am. Mineral., 94, 957-974, https://doi.org/10.2138/am.2009.2992, 2009.

Petrík, I., Broska, I., Lipka, J., and Siman, P.: Granitoid Allanite(Ce): Substitution Relations, Redox Conditions and Ree Distributions (on an Example of I-Type Granitoids, Western Carpathians, Slovakia), Geol. Carpathica, 46, 79-94, 1995.

Putnis, A.: Mineral replacement reactions: from macroscopic observations to microscopic mechanisms, Mineral. Mag., 66, 689708, https://doi.org/10.1180/0026461026650056, 2002.

Putnis, A.: Mineral Replacement Reactions, Rev. Mineral. Geochem., 70, 87-124, https://doi.org/10.2138/rmg.2009.70.3, 2009.

Putnis, A. and Austrheim, H.: Fluid-Induced Processes: Metasomatism and Metamorphism, Front. Geofluids, 11, 254-269, https://doi.org/10.1002/9781444394900.ch18, 2010.

Pyle, J. M. and Spear, F. S.: An empirical garnet (YAG) xenotime thermometer, Contrib. Mineral. Petr., 138, 51-58, https://doi.org/10.1007/PL00007662, 2000.

Pyle, J. M., Spear, F. S., Rudnick, R. L., and McDonough, W. F.: Monazite-Xenotime-Garnet Equilibrium in Metapelites and a New Monazite-Garnet Thermometer, J. Petrol., 42, 2083-2107, https://doi.org/10.1016/0022-328X(90)80211-H, 2001.

Raimondo, T., Payne, J., Wade, B., Lanari, P., Clark, C., and Hand, M.: Trace element mapping by LA-ICP-MS: assessing geochemical mobility in garnet, Contrib. Mineral. Petr., 172, 1-22, https://doi.org/10.1007/s00410-017-1339-z, 2017.

Regis, D., Cenki-Tok, B., Darling, J., and Engi, M.: Redistribution of REE, Y, Th and $\mathrm{U}$ at high pressure: Allanite-forming reactions in impure meta-quartzites (Sesia Zone, Western Italian Alps), Am. Mineral., 97, 315-328, 2012.

Schmid, S. M., Fügenschuh, B., Kissling, E., and Schuster, R.: Tectonic map and overall architecture of the Alpine orogen, Eclogae Geol. Helv., 97, 93-117, https://doi.org/10.1007/s00015004-1113-x, 2004.
Schulz, B.: Microstructural Evolution of Metapelites from the Austroalpine Basement North of Staller Sattel During Pre-Alpine and Alpine Deformation and Metamorphism (Eastern Tyrol, Austria), Jahrb. Geol. Bundesanstalt, 137, 197-212, 1994.

Seydoux-Guillaume, A.-M., Paquette, J.-L., Wiedenbeck, M., Montel, J.-M., and Heinrich, W.: Experimental resetting of the U-Th$\mathrm{Pb}$ systems in monazite, Chem. Geol., 191, 165-181, 2002.

Seydoux-Guillaume, A.-M., Montel, J.-M., Bingen, B., Bosse, V., Parseval, P. De, Paquette, J., Janots, E., and Wirth, R.: Lowtemperature alteration of monazite?: Fluid mediated coupled dissolution - precipitation, irradiation damage, and disturbance of the U-Pb and Th-Pb chronometers, Chem. Geol., 330-331, 140158, https://doi.org/10.1016/j.chemgeo.2012.07.031, 2012.

Skrzypek, E., Sakata, S., and Sorger, D.: Alteration of magmatic monazite in granitoids from the Ryoke belt (SW Japan): Processes and consequences, Am. Mineral., 105, 538-554, 2020.

Spear, F. S. and Pyle, J. M.: Apatite, Monazite, and Xenotime in Metamorphic Rocks, Rev. Mineral. Geochem., 48, 293-335, https://doi.org/10.2138/rmg.2002.48.7, 2002.

Spruzeniece, L., Piazolo, S., and Maynard-Casely, H. E.: Deformation-resembling microstructure created by fluidmediated dissolution-precipitation reactions, Nat. Commun., 8, 1-9, https://doi.org/10.1038/ncomms14032, 2017.

Steenken, A. and Siegesmund, S.: Cooling and exhumation of the Rieserferner Pluton (Eastern Alps, Italy/Austria), Int. J. Earth Sci., 91, 799-817, https://doi.org/10.1007/s00531-002-0260-4, 2002.

Stöckhert, B.: K-Ar determinations on muscovites and phengites from deformed pegmatites, and the minimum age of Old Alpine deformation in the Austridic basement to the South of the western Tauern Window (Ahrn valley, Southern Tyrol, Eastern Alps), Neues Jb. Miner., 150, 103-120, 1984.

Stöckhert, B.: Pre-Alpine history of the Austridic basement to the south of the western Tauern Window (Southern Tyrol, Italy) Caledonian versus Hercynian event, Neues Jahrb. Geol. P. M., 10, 618-642, 1985.

Stöckhert, B.: Das Uttenheimer Pegmatit-Feld (Ostalpines Altkristallin, Südtirol) Genese und alpine Überprägung, Erlanger Geol. Abhandlungen, 114, 83-106, 1987.

Suzuki, K. and Kato, T.: CHIME dating of monazite, xenotime, zircon and polycrase: Protocol, pitfalls and chemical criterion of possibly discordant age data, Gondwana Res., 14, 569-586, https://doi.org/10.1016/j.gr.2008.01.005, 2008.

Tropper, P., Manning, C. E., and Harlov, D.: Solubility of CePO4 monazite and YPO4 xenotime in $\mathrm{H}_{2} \mathrm{O}$ and $\mathrm{H}_{2} \mathrm{O}-\mathrm{NaCl}$ at $800^{\circ} \mathrm{C}$ and $1 \mathrm{GPa}$ : Implications for $\mathrm{REE}$ and $\mathrm{Y}$ transport during high-grade metamorphism, Chem. Geol., 282, 58-66, https://doi.org/10.1016/j.chemgeo.2011.01.009, 2011.

Tropper, P., Manning, C. E., and Harlov, D. E.: Experimental determination of $\mathrm{CePO} 4$ and $\mathrm{YPO} 4$ solubilities in $\mathrm{H}_{2} \mathrm{O}-$ $\mathrm{NaF}$ at $800^{\circ} \mathrm{C}$ and $1 \mathrm{GPa}$ : implications for rare earth element transport in high-grade metamorphic fluids, Geofluids, 1-9, https://doi.org/10.1111/gfl.12031, 2013.

Upadhyay, D. and Pruseth, K. L.: Fluid-induced dissolution breakdown of monazite from Tso Morari complex, NW Himalayas: evidence for immobility of trace elements, Comput. Geosci., 164, 303-316, https://doi.org/10.1007/s00410-012-0739-3, 2012.

Varga, J., Raimondo, T., Daczko, N. R., and Adam, J.: Experimental alteration of monazite in granitic melt: Variable 
$\mathrm{U}$ - Th - Pb and REE mobility during melt-mediated coupled dissolution-precipitation, Chem. Geol., 544, 119602, https://doi.org/10.1016/j.chemgeo.2020.119602, 2020.

Villa-Vialaneix, N., Montel, J.-M., and Seydoux-Guillaume, A.-M.: NiLeDAM: Monazite Datation for the NiLeDAM team, Packag. version $0.1, \mathrm{R}, 2013$.

von Blanckenburg, F.: Combined high-precision chronometry and geochemical tracing using accessory minerals: applied to the Central-Alpine Bergell intrusion (central Europe), Chem. Geol., 100, 19-40, 1992.

Wang, Y. and Marino, E.: Dynamic model of oscillatory zoning of trace elements in calcite: Double layer, inhibition, and selforganization, Geochim. Cosmochim. Ac., 56, 587-596, 1992.

Whitney, D. L. and Evans, B. W.: Abbreviations for names of rock-forming minerals, Am. Mineral., 95, 185-187, https://doi.org/10.2138/am.2010.3371, 2010.

Williams, M. L., Jercinovic, M. J., and Hetherington, C. J.: Microprobe Monazite Geochronology: Understanding Geologic Processes by Integrating Composition and Chronology, Annu. Rev. Earth Pl. Sc., 35, 137-175, https://doi.org/10.1146/annurev.earth.35.031306.140228, 2007.
Williams, M. L., Jercinovic, M. J., Harlov, D. E., Budzyń, B., and Hetherington, C. J.: Resetting monazite ages during fluid-related alteration, Chem. Geol., 283, 218-225, https://doi.org/10.1016/j.chemgeo.2011.01.019, 2011.

Wing, B. A., Ferry, J. M., and Harrison, T. M.: Prograde destruction and formation of monazite and allanite during contact and regional metamorphism of pelites: petrology and geochronology, Contrib. Mineral. Petr., 145, 228-250, https://doi.org/10.1007/s00410-003-0446-1, 2003.

Wölfler, A., Dekant, C., Frisch, W., Danišík, M., and Frank, W.: Cretaceous to Miocene cooling of Austroalpine units southeast of the Tauern Window (Eastern Alps) constrained by multisystem thermochronometry, Austrian J. Earth Sci., 108, 18-35, https://doi.org/10.17738/ajes.2015.0002, 2015a.

Wölfler, A., Frisch, W., Fritz, H., Danišik, M., and Wölfler, A.: Ductile to brittle fault zone evolution in Austroalpine units to the southeast of the Tauern Window (Eastern Alps), Swiss J. Geosci., 108, 239-251, https://doi.org/10.1007/s00015-0150193-0, 2015b. 